\title{
Romeyn de Hooghe's Hieroglyphica: An Ambivalent Lexicographical History of Religion
}

\author{
Trudelien van 't Hof
}

\begin{abstract}
This article analyses De Hooghe's Hieroglyphica as a contribution to the unfolding debate on what we have come to call 'enlightened religion'. First Van 't Hof demonstrates the mix of genres that shaped this unique and enigmatic book, with its 63 chapters built around often very complicated allegorical prints, with explanatory text as secondary to the imagery. Consequently the author identifies two main strands of argumentation contained in this intriguing volume, one historical and one comparative. Both channel a lot of contemporary critique on confessional religion. Many images depict the genealogy of religion as one of decline and corruption. The historical warp of the book serves to show that the original revelation of religious truths to Adam in Paradise has become fatally lost in translation among his descendants and how recent reformation aims at recovering its essence. In other images, that provide the woof of the overall argument, central dogmas of Latin Christianity are compared to very similar notions in the religions of Antiquity, in Judaism and Islam, in the Eastern Churches and in some of the exotic religions of the Far East and the Americas. Although De Hooghe had a reputation for libertinage, Van 't Hof, like Daudeij, does not interpret the author of Hieroglyphica as an advocate of irreligion. Rather, he problematised religion, and invited the reader to shape his own informed opinion.
\end{abstract}

Introduction

An ongoing theme in early modern historiography is the relation-or discrepancy-between (Christian) religion and the Enlightenment. Many early modern thinkers and writers, especially from the late seventeenth century, have been put to the test: Were their ideas orthodox Christian or (radical) Enlightened, or did they belong to the moderate middle ground in between? The quite contradictory labels given to seventeenth-century thinkers as a result of this research are remarkable. The foregrounding of one or another

(C) TRUDELIEN VAN 'T HOF, 2019 | DOI:10.1163/9789004389397_010

This is an open access chapter distributed under the terms of the prevailing CC-BY-NC License at the time of publication. 
aspect of their writings is supposed to provide the answer to what their 'real' ideas concerning religion were, which then defines the category they fit. So we find the Whig member of parliament Robert Howard (1626-89) labeled both a deist and an Anglican; the clergyman and scholar John Spencer (1630-93) is referred to as a Socinian or as an Anglican; the philosopher John Toland (16701722 ) is a radical freethinker and a critical Christian; the Swiss theologian Jean Alphonse Turretin (1671-1737) is portrayed as Socinian and Calvinist; and the religiosity of the theologian and philosopher Pierre Bayle (1647-1706) is still much debated. ${ }^{1}$

The same sense of apparent contradiction goes for the subject of this paper, a book by the Dutch artist Romeyn de Hooghe $\left(1645^{-1708)}\right.$ entitled Hieroglyphica (1735). If only a few elements from the book are selected, it can be seen as a radical work foregrounding the ingredients of Enlightened 'anticlericalism, historicization, and rationalization.' If one focuses on other parts, however, Hieroglyphica seems to be a product of a Reformed position that rejects 'new' philosophical ideas and stresses the authority of the Bible. The coexistence of elements in the book that could sustain contradictory judgments on De Hooghe's own position shows that Hieroglyphica, like many other early modern religious works, defies the classification of authors along the convenient lines of conservatism and Enlightenment. The larger question, then, is whether it makes much sense to stick such labels to authors and their books and to assume a division of the Enlightenment into different, and sharply demarcated, strands (radical, moderate, conservative/religious). Perhaps it is better to argue, as I will in this paper, that around 1700 the notions of true religion were complex, ambiguous, contradictory, and to some extent undecided. Furthermore, there are reasons to assume that this ambiguity was not solely the result of the rise of radical Enlightened philosophical insights. It also grew from within confessional Christianity, which was never as monolithic and inflexible as it is presented in some contemporary analyses. ${ }^{2}$

Without entering the theoretical debate about the exact nature of 'the Enlightenment,' or into the dynamic nature of theology in the confessional age, this chapter provides nuance to the idea that intellectuals of the time necessarily harbored fixed ideas about religion by examining the ambiguity and flexibility in the notion of true (Christian) religion in De Hooghe's remarkable Hieroglyphica.

1 See also Dmitri Levitin, 'From Sacred History to the History of Religion: Paganism, Judaism, and Christianity in European Historiography from Reformation to "Enlightenment,"' The Historical Journal 55 (2012), 1117-60, there 1159.

2 Levitin, 'From Sacred History to the History of Religion' (see above, n. 1), pp. 1119, 1133. 
Born in 1645 the son of a buttonmaker, Romeyn de Hooghe proved himself an excellent craftsman and acquired fame as one of the best, most productive engravers of his time. His etchings covered a range of topics, from depictions of battlefields and forays into political satire and theology to images showing beautiful gardens, judo skills, or pornographic scenes. The scholarly attention given to some of his work has not extended to his religious etchings. A good place to start here is his most important religious work: Hieroglyphica, of merkbeelden der oude volkeren, namentlyk Egyptenaren, Chaldeuwen, Feniciers, Joden, Grieken, Romeynen enz. Nevens een omstandig Bericht van het Verval en voortkruypende Verbastering der Godsdiensten door verscheyde Eeuwen; en eyndelyk de Hervorming, tot op deze Tyden toe vervolgt [Hieroglyphica, or emblems of the ancient peoples, Egyptians, Chaldeans, Fenicians, Jews, Greek, Romans etc. Containing an exhaustive essay on the progressive decline and corruption of religion through the ages, and its recent reformation until the present day]. The book, posthumously published in 1735, was written near the end of De Hooghe's life, probably around 1700. ${ }^{3}$ In Hieroglyphica De Hooghe combined sixty-three elaborate etchings with extensive accompanying texts presented in a series of chapters. Each chapter provides an elaborate legend for one image, and together the chapters provide a story of the emergence, decay, and reformation of religion, from its beginning in ancient times until De Hooghe's own period.

Although De Hooghe had a reputation for mockery and atheism in his own time, his overall production of religious etchings was enormous. He was no theologian, but nonetheless he illustrated and probably read many religious works and can be seen as a well-informed and interested layman, part of the 'elite of the skilled.' ${ }^{4}$ Such a characterization makes it interesting to look into the book that, rather than simply representing his illustrations of someone else's ideas on religion, was of De Hooghe's own conception, both in text and

3 Romeyn de Hooghe, Hieroglyphica, ed. Arnoldus Westerhovius (Amsterdam, 1735). Although it is not clear when exactly De Hooghe wrote Hieroglyphica, there are events mentioned which took place in 1702, indicating it was written in the years before his death in 1708 .

4 A term coined in Jonathan Israel, The Dutch Republic: Its Rise, Greatness, and Fall 14771806 (Oxford, 1995), pp. 348-51. For the phenomenon see also Patrick O'Brien, ed., Urban Achievement in Early Modern Europe: Golden Ages in Antwerp, Amsterdam and London (Cambridge, 2001), pp. 287-345; Wiep van Bunge, From Stevin to Spinoza: An Essay on Philosophy in the Seventeenth-Century Dutch Republic (Leiden, 2001), pp. 1-9; Arjan van Dixhoorn, Lustige geesten: Rederijkers in de Noordelijke Nederlanden (1480-1650) (Amsterdam, 2009). 
image. ${ }^{5}$ As such, Hieroglyphica can supplement and broaden the research into the religious ideas of theologians and philosophers by adding the opinions of a well-informed, skilled man hailing from a distinct sector of the middle class. In what follows I will present three cases in which De Hooghe's ideas concerning true religion are ambiguous or outright contradictory, preceded by some notions on how the genre and structure of the book-a combination of an emblematic lexicon and a history of religion-reflected conflicting views on key issues of religion and theology that De Hooghe shared with many of his contemporaries.

Genre and Structure: The Emblematic Lexicon and the History of Religion

The book's twofold title already points to Hieroglyphica's most remarkable feature: its combination of an encyclopedic visual compendium of religions and a verbal account of the historical development of religion. The first part of the title, Hieroglyphics or emblems of the ancient peoples, Egyptians, Chaldeans, Fenicians, Jews, Greeks, Romans etc., concerns the book's design, consisting of allegorical representations of the religions and gods of ancient peoples. The word Hieroglyphica refers to a long, complex tradition concerning ideographic scripts, especially Egyptian hieroglyphics. Greek thinkers viewed these hieroglyphs to be 'holy' signs, bearers of antique wisdom that could yield up the essence and origins of all things. ${ }^{6}$ The Renaissance witnessed a true cult of the hieroglyph, reviving classical ideas and myths about hieroglyphs as bearers of ancient wisdom, secrets, and the origins of things. Despite their popularity, this knowledge was not for everyone; hieroglyphs were believed to be open to the learned and closed to the vulgar. De Hooghe is critical toward 'veiled images' being bearers of religious deceit. At the same time, however, he used the symbols himself, which seems to indicate that the etcher uses this veiled language but applies it with a twist, so to unveil a different 'hidden religious meaning.'

5 The text, however, is not solely De Hooghe's. The book was published in 1735 (long after De Hooghe's death in 1708), after its text had been edited by a scholar of antiquity, Arnoldus Westerhovius (1677-1738). Although De Hooghe's images are the leading elements, and it seems that Westerhovius only added some elaborations, there is no complete certainty about authorship.

6 Margery Corbett and Ronald Lightbown, The Comely Frontispiece: The Emblematic TitlePage in England, 1550-1660 (London, 1979), pp. 22, 23; Erik Iverson, The Myth of Egypt and Its Hieroglyphs in European Tradition (Copenhagen, 1961), p. 46. 
Over time, however, hieroglyphs lost some of their arcane meanings and became just the equivalent of 'symbols,' 'allegorical images,' or even pictograms for the illiterate. Discussions about hieroglyphs resulted in many books that referred to them in their titles. De Hooghe was influenced by this vulgarizing symbolizing trend and himself contributed to the hieroglyph's vulgarization; he was an expert in the allegorical genre, especially as employed in frontispieces. But there were still connections in theory between hieroglyphs and frontispieces: like hieroglyphs, the design of frontispieces could and even should be 'open' and 'closed' at the same time. The iconography used should not be too enigmatic but certainly must not be too obvious either. It should require some form of decipherment and possess different layers of meaning, in order to intrigue and seduce people into buying the book. It is remarkable how frontispiece theory developed along the lines of hieroglyphical concealment. From the end of the Renaissance onward, title-print theory had become more iconographical and complex. Such complex symbolism needed to be not only new and inventive but also sharp-witted to prevent just any reader from readily understanding the image. Images, it was believed, needed to be 'closed to the vulgar and open to the learned.' Artists should avoid frontispieces that were too obscure and enigmatic, but they should also not produce images so commonplace that the invention required no decipherment. ${ }^{7}$

De Hooghe was sought after as an etcher of frontispieces. He practiced the art of the frontispiece on a yearly basis (for twenty years) for De Hollandsche Mercurius, a yearbook produced in Haarlem, where he lived. His contributions to these yearbooks offered a historical and political angle to the news. ${ }^{8}$ His skills in fashioning religious imagery and allegory were developed in the illustrations he made for numerous religious works. Important in this respect was his Alle de Voornaamste Historien des Ouden en Nieuwen Testaments [All

7 Liselotte Dieckmann, Hieroglyphics: The History of a Literary Symbol (St. Louis, 1970), pp. 18-21, 32, 44, 52; Roelof van den Broek, Corpus Hermeticum (Amsterdam, 1991), pp. 13-25; Corbett, The Comely Frontispiece (see above, n. 6), pp. 12, 31. See also Jetze Touber's contribution to this volume.

8 This popularity is especially underlined by the title prints Romeyn made for De Hollandsche Mercurius, a magazine discussing current affairs. For twenty years the author invented title prints based on the most important events of the year, which, considering the length of this period, must have been a great success. As every chapter seems to have its own hieroglyphic frontispiece, Hieroglyphica can be considered an extreme version of the title-print genre, a book completely consisting of title prints in which De Hooghe proved himself capable of making allegorical representations of the gist of the history of religion. Comparing the images of Hieroglyphica with the title prints for other (religious) works, one sees great resemblances in the depiction of the content, as well as the composition, style, and allegorical approach. 
the most relevant Histories from the Old and New Testaments] (1703). ${ }^{9}$ In this work, De Hooghe provided the most important biblical stories with images that were halfway between illustrations and frontispieces combining various biblical stories. These engravings were intended for insertion into the Lindenberg Lutheran Bible. Many buyers had these images bound with their copies of the Bible, although this was prohibited by the Lutheran church. Furthermore they were re-used in Jacobus Basnage's (1653-1723) 't Groot Waerelds Tafereel [The Great Theater of the World] $(1705 / 6) .{ }^{10}$ Like De Hooghe's illustrations for Hieroglyphica's world history, his etchings for Lindenberg's biblical history also combine different genres, encompassing text and images, historical timetables, geographical maps, and moralizing poetry. This mixture of all kinds of elements was probably intended to appeal to a larger public and therefore contribute to higher sales."

The figures, style, composition, and allegories of the etchingsin Hieroglyphica match the format of title-print images - they were meant to grasp the core message of the books for which they were made. ${ }^{12}$ The title print of a book was

Romeyn de Hooghe, Alle de Voornaamste Historien des Ouden en Nieuwen Testaments Verbeeld in uytsteekende Konst-Platen, door den Wyd-beroemden Heer, en Mr. Romeyn de Hooghe. Met omstandige verklaring der Stoffen, en seer beknopte Punt-Digten, van den Eerw. Godsgel. Heer Henricus Vos. Waar by ook gevoegt zyn Nieuwe Kaarten, tot Opheldring der zaaken nodig (Amsterdam, 1703).

10 Jacobus Basnage, 't Groot Waerelds Tafereel, waarin de Heilige en Waereldsche Geschiedenissen en Veranderingen zedert de Scheppinge des Waerelds tot het Uiteinde van de Openbaaring van Johannes, worden afgemaalt, en ider Konst-prent door Godsgeleerde Wysgeerige en Waereldlyke Uitleggingen, Redeneeringen en Gedachten verciert. Benevens de Naaukeurige Tydreekeningen of Jaarboeken der Gevallen des Waerelds (Amsterdam, 1705/1706); Wilco C. Poortman, De Prentbijbel van Romeyn de Hooghe (Amsterdam, 1980); idem, "De prentbijbel van Romeyn de Hooghe," De Hoeksteen 7 (1978), 83-90.

11 See for similar methods: Jo Spaans and Trudelien van 't Hof, Het beroerde Rome, spotprenten op de paus, in een pleidooi voor een 'Nederlandse' katholiek kerk, 1705-1724 (Hilversum, 2010).

12 Garrelt Verhoeven and Piet Verkruijsse, 'Verbeelding op bestelling,' in: Henk van Nierop, ed., Romeyn de Hooghe: De verbeelding van de late Gouden Eeuw (Zwolle, 2008), pp. 14669, there 151. William Harry Wilson, The Art of Romeyn de Hooghe: An Atlas to European Baroque Culture (Cambridge, 1974), p. 6. Marjan Balkestein, ed., 'Doorgaens verciert met kopere platen': Nederlandse geillustreerde boeken uit de zeventiende eeuw (Leiden, 1990), p. 48. Already in his own time De Hooghe's quality and inventiveness were noticed by his colleagues, even though they abhorred his behavior. The painter and writer Arnold Houbraken wrote: "Hy [Romeyn de Hooghe] [was] een man uitsteekend in groot vernuft en in vindingen, en die ik niet weet dat zyns gelyk in vaardigheid van orderneeren, in rykheid van veranderingen in de Etskonst gehad heeft waar van het oneindig getal van Boektytels en andere Printen getuygenis geven." [He (Romeyn de Hooghe) was a man who excelled in intelligence and invention, and a man unlike anyone in the skill of composition and in the wealth and variety of innovations as is witnessed by the innumerable number of book titles and other prints.] Arnold Houbraken, De groote schouburgh der 
supposed to serve as the pictorial equivalent of the book's text; it needed to depict the complex core of the book in one image that would arouse the curiosity of potential readers. To carry out such a difficult task artists most of the time made use of allegorical imaginations, full of symbols and personifications. The ideal title print consisted of a creative and new composition of allegorical elements, which could be fully understood only by reading the book. Worn-out and well-known allegories, lacking any new approach, would not have been sufficient for the production of an interesting, attractive frontispiece. ${ }^{13}$

In Hieroglyphica the images are the prime medium, which is unusual, since 'hieroglyphic' frontispieces were usually considered to be mere embellishment and in any case of secondary importance to the texts for which they were made. But the hermetical, arcane connotation of the hieroglyphic genre was foregrounded in Hieroglyphica. ${ }^{14}$ Both De Hooghe's fascination with Egypt, and the sources he used - such as the work of Athanasius Kircher (1602-80), the Hieroglyphica (1556) of Pierius Valerianus (1477-1558), and the Mensa Isiaca - indicate that De Hooghe chose to present religion as an enigma. ${ }^{15}$ In his combination of hieroglyphs and religion De Hooghe was not unique: the late seventeenth and early eighteenth centuries saw a vogue in 'emblematic theology,' a genre in which biblical exegesis was practiced on several levels in a search for the deepest meaning and most complete understanding of the text. Several books containing 'hieroglyphical' biblical exegesis were published. ${ }^{16}$ Examples are Hendrik Groenewegen's (ca. 1640-92)

Nederlantsche konstschilders en schilderessen, 3 vols. (Amsterdam, 1718-1721), 3: 257-9. De Hooghe's facility in invention and his creativity in his works were appreciated not just for their artistic quality but also because of their commercial value. This was especially applicable to title prints made by the sort of gifted etcher Romeyn de Hooghe was, and this was likely the main reason that De Hooghe, although he was relatively expensive, was frequently asked to design and produce of all kinds of frontispieces. Christian Coppens, Een Ars moriendi met etsen van Romeyn de Hooghe (Brussels, 1995), p. 63.

13 Corbett, The Comely Frontispiece (see above, n. 6), pp. 34, 35, 37.

14 He mentions that he is going to treat the subject in a way nobody had done before: combining hieroglyphs, characters, and historic persons together in one image. "De manier van 't verhandelen deser Stoffe is sodanig als mijns wetens noch van niemand niet gebruyckt en is, en 't samen gevoegt uyt verscheyde soorten, as Hieroglyphen, Characters en Historiele persoonen." Romeyn de Hooghe, Schouburgh der Nederlandse veranderingen (Amsterdam, 1674), p. 6; De Hooghe, Hieroglyphica (see above, n. 3), pp. $12,15$.

15 See Athanasius Kircher, Obeliscus Pamphilius (Rome, 1650); idem, Oedipus Aegyptiacus (Rome, 1652-5); idem, Latium (Amsterdam, 1671). See also Jocelyn Godwyn, Athanasius Kircher's Theatre of the World (London, 2009).

16 W. J. van Asselt, 'De neus van de bruid, de "profetische" en "zinnebeeldige" godgeleerdheid van Henricus Groenewegen en Johannes d'Outrein,' in: Profetie en godsspraak in de geschiedenis van het christendom: Studies over de historische ontwikkeling van een opvallend verschijnsel, ed. F. G. M. Broeyer and E. M. V. M. Honée (Zoetermeer, 1997), pp. 163-84. 
Hieroglyphica, anders Emblemata sacra (1693), Salomon van Til's (1643-1713), Zoologica Sacra (1714), Nicolaas Lydius's (†1687) Lexicon Hieroglyphicum, and most famously Johannes D'Outrein's (1662-1722) Proefstukken der heilige sinnebeelden [Examples of holy emblems] (1700) and Martinus Koning's (1662-1733) Lexicon Hieroglyphicum Sacro-Profanum (1722). In many of these books seemingly neutral words (for animals, stones, minerals, etc.), ordered alphabetically into a lexicon, were infused with sacred meaning. Although De Hooghe's Hieroglyphica resembles these works and fits the emblematic worldview of the theological works mentioned, Hieroglyhpica's style, structure, and scope was much broader than biblical exegesis only. In Hieroglyphica we recognize the mythographical genre of the Renaissance, in which classical deities were analyzed and elaborated on in their historical, religious, and artistic aspects. Famous examples of this genre were the handbooks of classical mythological gods by Vincenzo Cartari (ca. 1531-69), Giglio Giraldi (1479-1552) and Natale Conti (1520-82). ${ }^{17}$ Dutch examples are Carel van Mander's (15481606) Schilderboeck (1604) and Johannes Aysma's Het Ryck der Goden onder den Eenige waare God. In veel Heerlijke Vertooningen van Goddelijke Bewijsen, naturelijke Speculatien, politijke Bedenkingen, aanmerkelijke Geschiedenissen, soete Poëzyen, Sinrijke Verbeeldingen, insonderheid, der Elementen en der voornaamste Goden, neffens derselver Letter-kundige Benaamingen en Beduydingen, als mede Reedelijke, Zeedige en Grondige Toepassingen, etc. [The Reign of the Gods under the Only true God. I many Delectable Expositions on divine Proofs, natural Speculations, political Considerations, remarkable Histories, sweet Poetry, Meaningful Illustrations, especially of the Elements and the principal Gods, as well as their literary Names and Epithets, and Reasonable, Moral and Elementary Uses] (1686). ${ }^{18}$ But again, De Hooghe took an original path. Instead of ordering the classical lexicographical gods or topics separately and alphabetically, or explaining biblical words and lemmas in an emblematic way as his predecessors had, he combined material from both genres and included them chronologically in a much broader history of religion, going beyond Christian

17 Giglio Gregorio Giraldi, Historia de deis gentium (Basel, 1548); Vincenzo Cartari, Le imagini con la spositione de i dei de gli antichi [Images depicting the gods of the ancients] (Venice, 1556); Natale Conti, Mythologiae sive explicationis fabularum libri decem, in quibus omnia prope Naturalis \& Moralis Philosophiae dogmata contenta fuisse demonstatur (Venice, 1567). This genre was especially popular in Germany; in 1744 Hieroglyphica was translated into German, supplemented with an introduction by the Halle theologian Siegmund Baumgarten. Johannes Aysma, Het Ryck der Goden (Amsterdam, 1686). 
history into what Guy Stroumsa considers to be the start of "a new science," namely the history of 'religion' in general. ${ }^{19}$

\section{$4 \quad$ A Comparative Approach to Religions, Ambiguity, and a Focus on Decay}

De Hooghe's lexicographic history not only broadened the scope of emblematic theology but also provided an image of true religion that was rather ambiguous and uncertain. Moreover, unlike most contemporary authors on the history of religions, De Hooghe is reluctant to measure other religions with the yardstick of his own or any other confessional orthodoxy.

This sort of orientation is engendered by the twofold structure of De Hooghe's historical account, which alternates between a chronological and a thematic approach roughly corresponding to, respectively, notions of sacred history and the broader, 'profane' history of religion. ${ }^{20}$ On the one hand, De Hooghe's chronological account-exceeding the boundaries of the genre of ecclesiastical history-contains a sacred history, presenting the story of God's unique, chosen peoples from Adam and Eve, via the Israelites and Jews, to the Christians. Adhering to the theory of separation, the account shows pagan religions to be present in this story but most of the time they are separated from the Judaic and Christian religions.

This sacred history, chronologically organized, is challenged by De Hooghe's thematic comparative etchings that interrupt his chronological line and follow the identification theory. This theory was the obverse of the separation theory: instead of emphasizing the gap between true and false histories and religions, it foregrounded the similarities among religious stories and searched for areas of identification between pagan and Christian religions. ${ }^{21}$ Whereas the first theory denounced rival religious stories as fictions, the second theory was based on the conviction that the ancient East was an environment in which

19 Guy Stroumsa, A New Science: The Discovery of Religion in the Age of Reason (Cambridge, 2011).

20 In the sense in which Jonathan Sheehan makes this distinction: profane as opposed to sacred, not in the current meaning of 'nothing to do with religion.' Jonathan Sheehan, 'Sacred and Profane: Idolatry, Antiquarianism and the Polemics of Distinction in the Seventeenth Century,' Past \& Present 192 (2006), 35-66.

21 Paolo Rossi, The Dark Abyss of Time: The History of the Earth and the History of Nations from Hooke to Vico, trans. L. Cochrane (Chicago, 1987) pp. 152-7; Stroumsa, A New Science (see above, n. 19). 
wise men, even before Christ, grasped valuable notions of the true religion, most importantly monotheism. ${ }^{22}$

Although the figures he used were not original - they were probably imitations of Valeriano's Hieroglyphica from 1556-the combination and composition of images were rather unique. Most other artists and authors categorized their material per distinct religion, treating these religions in separate chapters. Alexander Ross's (ca. 1590-1654) Pansebeia-from which De Hooghe used a considerable amount of information-dealt with each religion in a discrete chapter, and the same goes for the famous Cérémonies et Coutumes religieuses de tous les peuples du monde (1723-37) by Jean Bernard (1680-1744) and Bernard Picart (1673-1733), which consisted of distinct volumes for each of the religions considered. De Hooghe adopts a thematic approach, combining similar concepts found in different religions within a unifying frame. The matters depicted are to some extent also inconsistent with the tendency in books of this genre to focus on customs and habits: baptism, funerals, marriages, and sacrifices. De Hooghe's oeuvre shows that he did produce etchings on the ceremonial aspects of religion, for instance the Jewish funeral and mourning at a cemetery, and on dying in Catholicism, but in Hieroglyphica almost all the topics concern quite theoretical issues of faith. ${ }^{23}$ These comparative etchings can be considered examples of an increasing tendency within the genre of the history of religions' to emphasize the historicity of religion and thereby to debunk the sacred character of canonical traditions, including those of Christianity.

Finally, De Hooghe's historical focus on religious decline is part and parcel of his ambiguous history of religion. This history of decline which he presents in his emblematic images is already announced in the second part of the title, namely the exhaustive essay on the progressive decline and corruption of religion through the ages, and its recent reformation until the present day. From the Egyptian, Roman, and Greek religions to Christianity and Islam, De Hooghe points out the signs of decay: religious abuse, schism, violence, and persecution. History proves itself to be full of examples, almost from the very beginning. Whereas the original true religion-written in hieroglyphic script by the biblical Seth (fig. A) in plate 2 (Fig. 8.1) - is positioned in the background and described in very general terms, most attention is given to kings, philosophers, and priests, who have perverted religion for their own ends to increase their

22 D. P. Walker, The Ancient Theology: Studies in Christian Platonism from the Fifteenth to the Eighteenth century (London, 1972); Jan Assmann, Moses the Egyptian: The Memory of Egypt in Western Monotheism (Cambridge, Mass., 1997), especially 76-9o. Peter Harrison, 'Religion' and the Religions in the English Enlightenment, pp. 132-8.

23 More customary topics are present, but very few: only the ritual of excommunication is presented in the comparative plate 51 . 


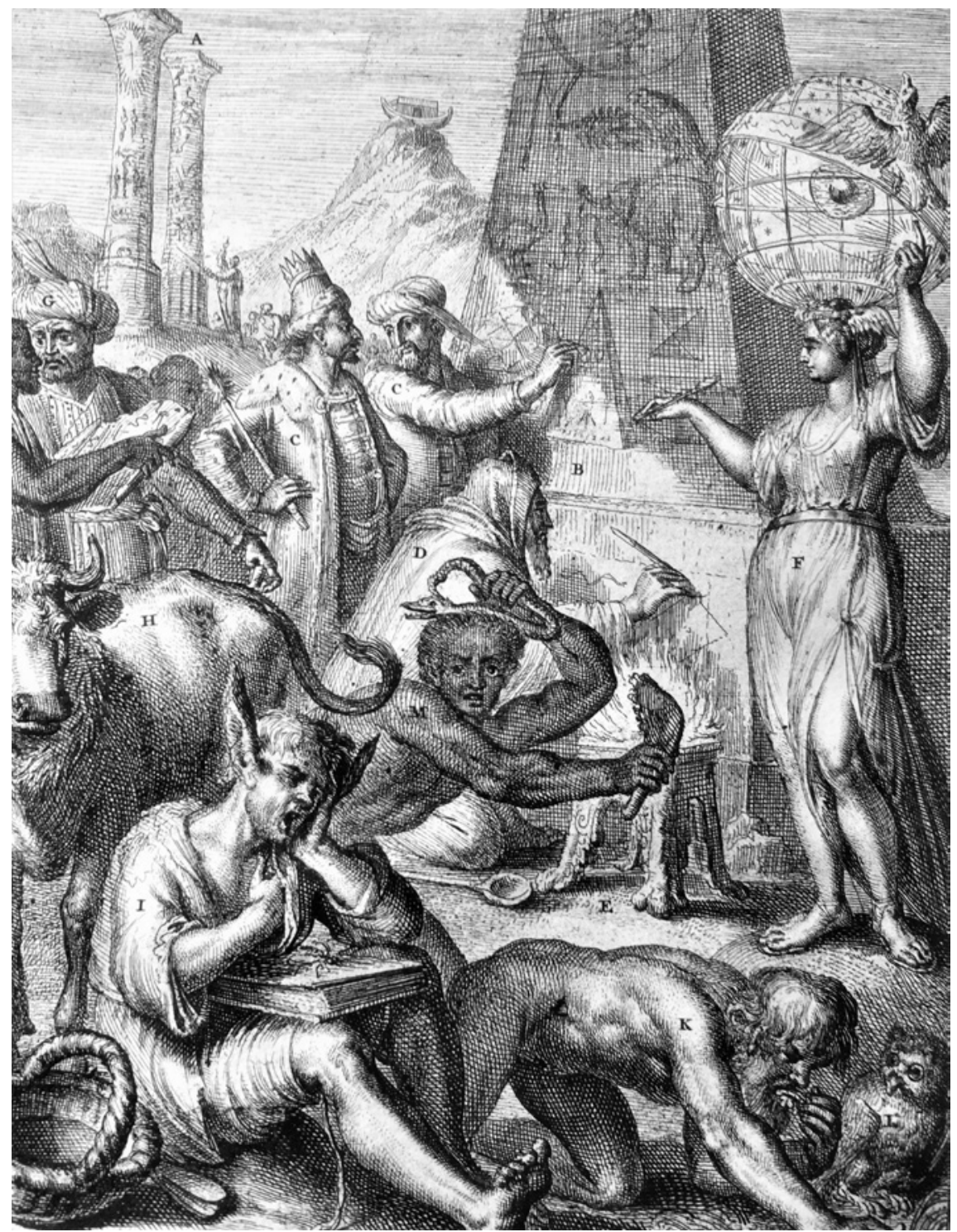

FIGURE 8.1 Rakende de Naam en Eerste Gang van de Hieroglyphica of Beeldspraak-Konst in het algemeen [On the Meaning of the term Hieroglyphics and the emergence of the Art in general], plate 2, in: Romeyn de Hooghe, Hieroglyphica (Amsterdam, 1735). Private collection 
power and keep the masses in check. ${ }^{24}$ Against this perennial religious decline, ongoing reformation was required, within the Protestant churches as much as any other. ${ }^{25}$

This approach, highlighting historical religious corruption, has been interpreted as radical, for instance in the work of Jonathan Israel, who places the argument of religious decline almost entirely within a radical Spinozistic program. ${ }^{26}$ As such, however, the view that religion had declined throughout the ages was not radical at all, and certainly not new. Ever since the writings of the first church historian, Eusebius of Caesarea, historians have presented the history of Christianity to be a story of error and deviation from the original conception of the Apostolic Church, and the decline usually involved theological innovations. For 'new' religions, the only way to avoid the accusation of novelty was to prove that the new or adapted form of religion was not in fact new but rather a return to the ancient, pure, and true form of Christianity. Such a return had become necessary because the established Church had been corrupted, a line of reasoning especially popular during the Protestant era. ${ }^{27}$

The remainder of this chapter will demonstrate De Hooghe's line of reasoning, as analyzed above, on three ambiguous topics elaborated on in his Hieroglyphica in order to show how contradictory opinions and suggestions could coexist in early modern sources such as Hieroglyphica. Instead of considering such a work partly 'unreliable' or a half-hearted cover-up for radical ideas, I would opt for the possibility that it presents various solutions for an undecided question, presenting two different lines of thought at the same time and leaving it to the reader to choose between them, or not. ${ }^{28}$ Besides

24 De Hooghe, Hieroglyphica (see above, n. 3), p. 25.

25 Trudelien van 't Hof, 'Radicale, partisane ou idéaliste? La présentation historique par De Hooghe du déclin de la religion et de la Réformation dans ses Hieroglyphica,' in: Les Protestants à l'époque moderne : Approche anthropologique, ed. Olivier Christin and Yves Krumenacker (Rennes, forthcoming).

26 Jonathan Israel, Enlightenment Contested: Philosophy, Modernity, and the Emancipation of Man 1670-1752 (Oxford, 2006), pp. 94-114. Israel, ignoring the fact that the concept of religious decline was used in a very broad religious domain, describes it as a "profoundly Spinozistic idea": ibid., p. 98.

27 For decline and reformation as a very common interpretative model for (Protestant) church history see e.g. Peter van Rooden, Religieuze Regimes: Over godsdienst en maatschappij in Nederland 1570-1990 (Amsterdam, 1996), p. 149. It was used in an extreme form by Gottfried Arnold (1666-1714), also a source for De Hooghe.

28 See also the notion of 'selective neutrality' in Jetze Touber, 'Religious Interests and Scholarly Exchange in the Early Enlightenment Republic of Letters: Italian and Dutch Scholars, 1675-1715,' Rivista di Storia della Chiesa in Italia 2 (2014), 411-36. De Hooghe may also have derived this approach from academic culture, in which academic freedom allowed free discussion on any theological matter not decided upon by a national synod. Cf. A. C. Duker, Gisbertus Voetius, 4 vols. (1897-1915; repr. Leiden, 1989), 3:87-102. 
the analysis given below, a more down-to-earth approach to the matter of ambiguity should be kept in mind, namely the possibility that contradiction and dissimulation were also part of a lucrative strategy involving the mystification of one's work. The very idea that a text was coded and needed deciphering appealed to readers and could therefore incite people to actually read (and buy) a treatise or book. ${ }^{29} \mathrm{~A}$ similar suggestion has been made about images. In his contribution to the edited volume Art in History/History in Art, Jochen Becken states that

offering several different comments on the same picture was a rather popular game in seventeenth-century society. [...] There is no reason why we should not suspect that the painter, too, intended different "solutions" or at least left the meaning of the picture open. A picture is thus seen as an ambiguous communication (text) to be treated in a variety of ways. ${ }^{30}$

De Hooghe's ambiguity pops up several times with regard to smaller issues in Hieroglyphica, but also when he addresses topics that were quite contested. Three topics will be discussed below in which a clear idea about true religion or religious truths is lacking and images and text alike are ambiguous. These topics are, respectively, the dogma of predestination, the reality of the devil and demonic influence on people, and the role of priestcraft in religion. In all these matters De Hooghe is unclear about the specific content and authority of religion, which can be connected to a changing perspective on the history of religion (shifting from sacred history to a more comparative history of religions) resulting in a moderate attitude toward the specific dogmas of true religion.

Connected to the relation between Christianity and other religions is the question of the extent to which similarities existed between them. This topic is present in De Hooghe's comparative etchings, where the presentation of similarities between religions puts the authority of Christianity and its teachings on a par with that of other religions, questioning the unique, 'revealed'

29 See Mara van der Lugt, 'The True Toland? Inquiry Into the Religious Writings of an Irreligious Mind' (M.A. thesis, Erasmus University Rotterdam, 2010). See also idem, Bayle, Jurieu, and the Dictionnaire Historique et Critique (Oxford, 2016).

30 Jochen Becker, 'Are These Girls Really So Neat? On Kitchen Scenes and Method,' in: Art in History/History in Art: Studies in Seventeenth-Century Dutch Culture, ed. David A. Freedberg and Jan De Vries (Santa Monica, Calif., 1991), pp. 139-74. 
origin of several of the Christian dogmas. In plate 6 multiple creation stories are juxtaposed under the title 'De Scheyding van de Chaos, of War-klomp' [On the separation of primeval chaos], highlighting their similarities, while the Christian dogma of 'creation from nothing' is absent. In plate 62 several hereafters are present, showing the options for true heaven to be quite broad. Such a comparative view on religion was itself not radical. The Christian religion had long been compared to other religions - to Judaism, for instance-in order, most of the time, to point to its superiority and exclusive truth claims. Still, in De Hooghe's images such a superiority is not clearly expressed: his juxtaposition could either mean that a certain Christian dogma had been invented, too, or that pagans' dogmas were imitations of the true Christian ones. Here we enter the field of the comparative history of religions, characterized by a less confessionally biased view on religion in which similarity is more foregrounded than difference. Whereas this development is traditionally traced to the nineteenth century, a growing body of research indicates that it started in the seventeenth century. ${ }^{31}$

The first comparative chapter is chapter 5 , 'Van de Voorbeschikking en het Noodlot' [On Predestination and Fate] (Fig. 8.2). The engraving shows us the concept of fate in a number of religions, such as the classical Roman, Greek, and Phoenician religions. The accompanying text is rather elaborate in its introduction of the etching. It starts by explaining how scientists gained increasing power from their knowledge of the natural world and from developments in shipping, the domestication of animals, the discovery of herbs' medicinal properties, and other such areas. The scientists' knowledge, combined with their strong ties to political power, made the masses willing to listen and obey them. Over time, these scientists became more like priests, claiming to be intermediaries between men and gods and able therefore to foretell the future. The uncertain people, lacking knowledge, started to ask these 'artists and knowers' for counsel and predictions. ${ }^{32}$ This was, according to De Hooghe, a tricky business; "if the answers did not match the course of events, their [i.e., the scientists' / clerics'] highly esteemed status would be overthrown; but to protect themselves against such storms they invented Fate." ${ }^{33}$ Whenever the

\footnotetext{
31 A. Molendijk, The Emergence of the Science of Religion in the Netherlands (Leiden, 2005). Stroumsa, A New Science (see above, n. 19).

32 "De raadvragers, de vertwyffelden, en bevreesden, antwoord van den Priesters ontfangende, zouden, als de antwoorden met de zaken niet over een kwamen, den ontzagchelyken staat der Priesters over hoop geworpen hebben; maar om zig zelven tegen zulke stormen te beveyligen, vonden zy het Noodlot uyt." De Hooghe, Hieroglyphica (see above, n. 3), pp. $67-9$.

De Hooghe, Hieroglyphica (see above, n. 3), p. 69.
} 


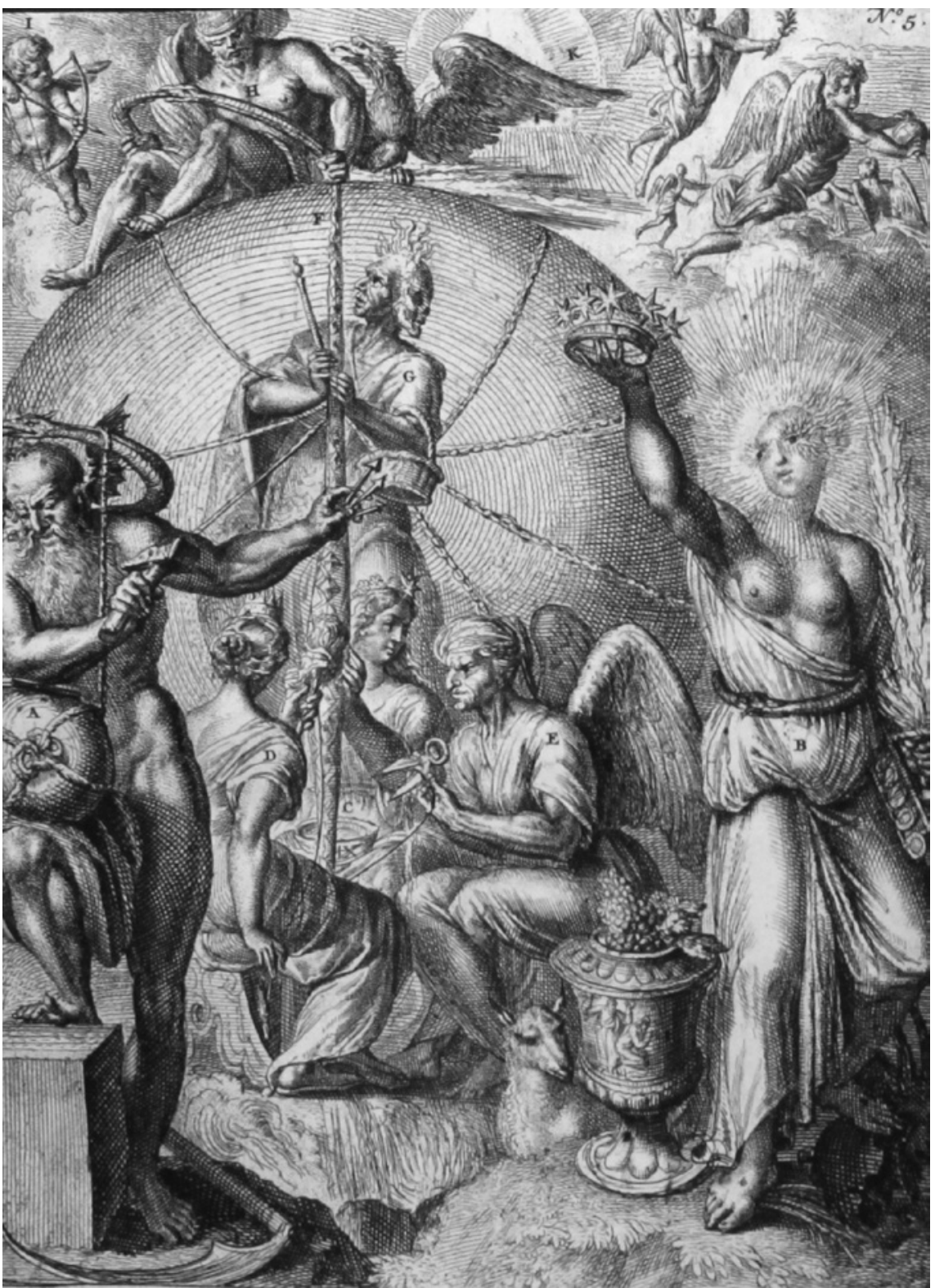

FIGURE 8.2 Van de Voorbeschikking en het Noodlot [On Predestination and Fate], plate 5, in: Romeyn de Hooghe, Hieroglyphica (Amsterdam, 1735). Private collection 


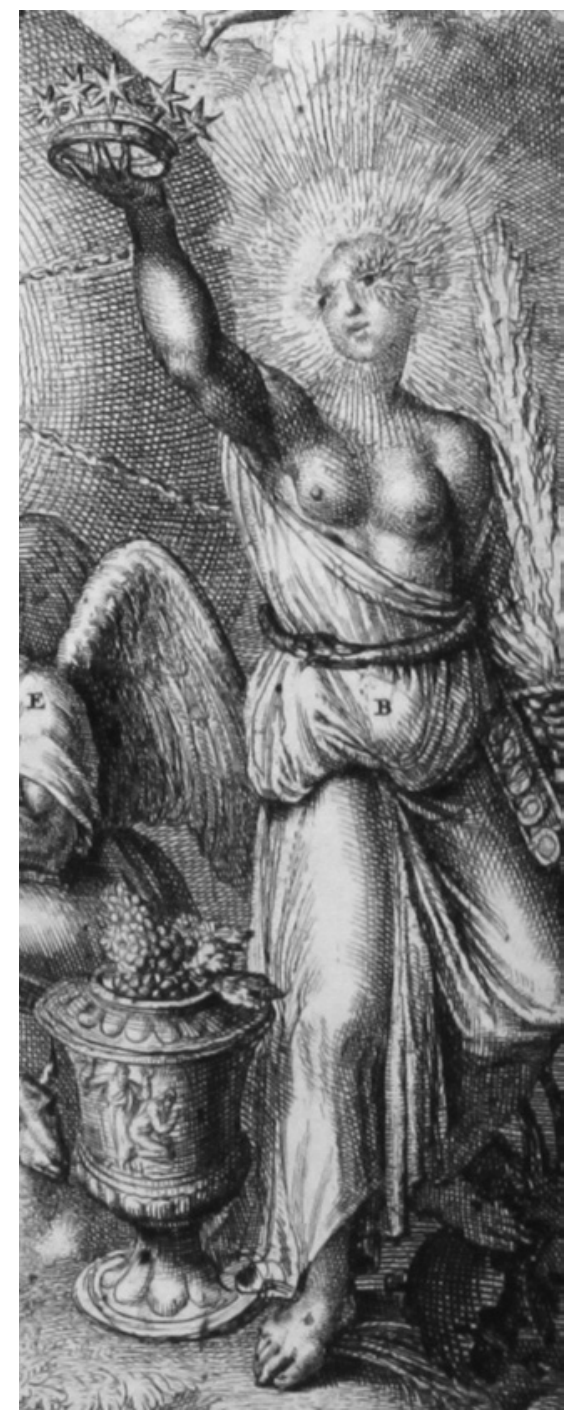

FIGURE 8.3

Eeuwige Voorzienigheid [Eternal Providence], detail B from plate 5 , in: Romeyn de Hooghe, Hieroglyphica (Amsterdam, 1735). Private collection

predictions of these clerics proved wrong, they told their followers that it was because 'fate' had ultimately decided differently. Very remarkable here is the presence of the Christian dogma of predestination in this image, depicted as the woman in figure B (Fig. 8.3). ${ }^{34}$

34 De Hooghe calls this figure 'Eternal Providence,' but the explanatory legend speaks about predestination. 
The doctrine of predestination was highly debated in the seventeenthcentury quarrels between the Arminians (named after Jacobus Arminius, 1560-1609, and later labeled Remonstrants) and Gomarists (followers of Franciscus Gomarus, 1563-1641, later to be called Counter-Remonstrants). In this debate the matter of predestination was the main bone of contention. Orthodox theologians viewed the lives and the afterlives of human beings as predestined, without the possibility that one could influence the course of events by the exercise of free will, and saw this doctrine as necessary for salvation. ${ }^{35}$ Remonstrants endorsed a milder form of predestination in which, for instance, humans needed to actively accept God's grace. Remonstrants, who restricted their list of essentials to "the faith in the Bible as the Word of God, the willingness to live according to Biblical precepts, the belief in Christ as the Saviour of humanity and the belief in the immortality of the soul,"36 did not perceive the doctrine of predestination and the lack of free will to be necessary for salvation. So the question here is why this figure stands between these gods of Fate invented by pagans. Did De Hooghe insert figure B into this engraving to underscore the Christian dogma by showing that even the ancient pagan religions had ideas about predestination? Or does this positioning of Eternal Providence between similar pagan inventions point to the non-original and extra-biblical character of this highly debated doctrine? Maybe we will never know the precise message De Hooghe wanted to convey, but the least he achieved was to create an ambiguous sphere that allows one to read both an orthodox and a radical point of view.

Supporting the more radical stance is De Hooghe's overall lack of much attention to predestination. At several points in Hieroglyphica De Hooghe gives short lists detailing what the basis of true religion is, and nowhere is predestination mentioned. ${ }^{37}$ Moreover, when De Hooghe does mention predestination, he predominantly presents it as a cause of religious and political dissension, resulting in chaotic unrest and conflict. ${ }^{38}$ Chapter 61 , for example, touched on Arminian theology briefly in the description of its figure E. Here De

35 Cocceius also endorsed the orthodox view on predestination, and the connection within theology. He did place emphasis on the historicity of the salvation. When he was accused of Arian tendencies, he furiously stated that this was due to Voetius misinterpreting him: J. W. van Asselt, 'Voetius en Coccejus over de rechtvaardiging,' in: De onbekende Voetius. Voordrachten wetenschappelijk symposium Utrecht 3 maart 1989, ed. J. van Oort et al. (Kampen, 1989), pp. 32-47, there 40.

36 Sibbe Jan Visser, Samuel Naeranus (1582-1641) en Johannes Naeranus (1608-1679): Twee remonstrantse theologen op de bres voor godsdienstige verdraagzaamheid (Hilversum, 2011), pp. 25, 26.

37 See the chapter about the fundamentals of true religion in my forthcoming $\mathrm{PhD}$ thesis.

38 "The large Churches of the Christians are mostly destroyed by the Turks and the Mahometans - as is drawn here in the distance-after they wore out their powers by 
Hooghe loosely notes that after the Reformation, the Dutch Reformed Church did not remain free from disturbance and factional strife, as some "hot-heated thinkers liked to dally with newly revived theological enigmas." ${ }^{39}$ De Hooghe points here to the Arminian controversy. Again, like the explanatory text with Arius in chapter 36 , he ignores the doctrinal issues-except for mentioning that it concerned old theological matters (and enigmatic ones at that) — but emphasizes the discord, conspiracy, and murder it resulted in:

Jacob Arminius published five divisive articles; Episcopius refined the work; and others increased the differences to the point of Massacres in several cities, [opposing] the abuse of power in the highest circles of the Free Dutch Republic, which developed into imprisonment, decapitation and plotting of the most influential [people], before the storm calmed. ${ }^{40}$

Throughout Hieroglyphica there is additional emphasis on peace and the relative freedom of church members. Interesting in this regard is chapter 35 , 'On the Peace of God's Church,' in which the female depicted in the center of the plate in figure A is the Peaceful Church, Christ's bride, representing the Church as an institution, and figure B is her sister, Freedom of Inquiry (Figs. 8.4 and 8.5). ${ }^{41}$

The heading reveals a link with the predestination quarrel between Remonstrants and Counter-Remonstrants, as it resonates with the title of a resolution promulgated in 1614, 'Resolution for the Peace of the Church,' which Hugo Grotius was commissioned by the States to write. In this resolution, ministers were told exactly what they should teach their flocks in matters related to the five points of the Arminians. ${ }^{42}$ In this decree the doctrines of the Remonstrants were believed to be sufficient for salvation, and ministers were

internal discord, after which they were powerless against the attack of the Muslims, Saracens and Turks." De Hooghe, Hieroglyphica (see above, n. 3), p. 333.

39 De Hooghe, Hieroglyphica (see above, n. 3), p. 347.

40 De Hooghe, Hieroglyphica (see above, n. 3), p. 347. Episcopius was a student of Arminius and one of the leading Arminian theologians.

41 "De Vreede van Gods Kerk (Het Lieffelykste boven alles) het Ware Salem, word verbeeld als een zeer beminnelyke, aangename en schoone Bruyd...." De Hooghe, Hieroglyphica (see above, n. 3), p. 269. With Salem De Hooghe makes reference to several passages in the Bible where Salem is representative of Peace, either as the place where Melchizedek was king or as another name for Jerusalem.

42 See the Resolutie ... tot den vrede der kercken [Resolution ... for the Peace of the Churches] (The Hague, 1614). Grotius's text was seen as too Remonstrant, he was imprisoned in Slot Loevestein where he wrote Het bewijs van de ware Godsdienst [Demonstration of the True Religion], published first as idem, Sensus librorum sex, quos pro veritate religionis Christianae Batavice scripsit (Leiden, 1627). 


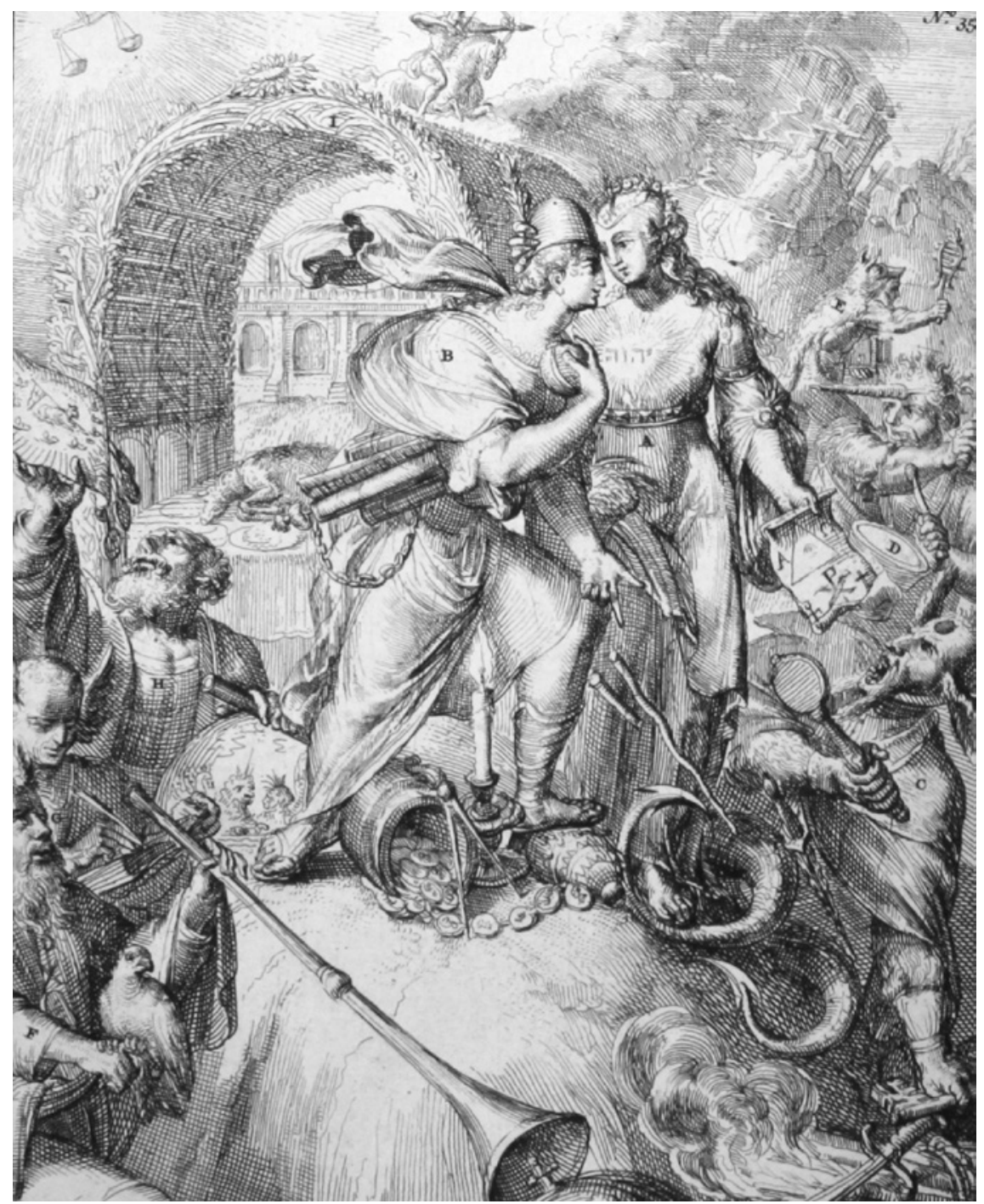

FIGURE 8.4 Van de Vrede van Gods Kerk [On the Peace of God's Church], plate 35, in: Romeyn de Hooghe, Hieroglyphica (Amsterdam, 1735). Private collection

no longer permitted to preach on predestination. That De Hooghe chose this title could indicate that he preferred the Remonstrant stance on the issue, but the question is whether he even had a preference, because his emphasis is on peaceful coexistence within the church. In chapter 35 this is visualized in the two sisters, A and B. According to De Hooghe, it is peace, given to the Church by the Holy Spirit, that encourages Christian freedom for its members. This liberty existed in the freedom to search the divine writings for hidden treasures, a 


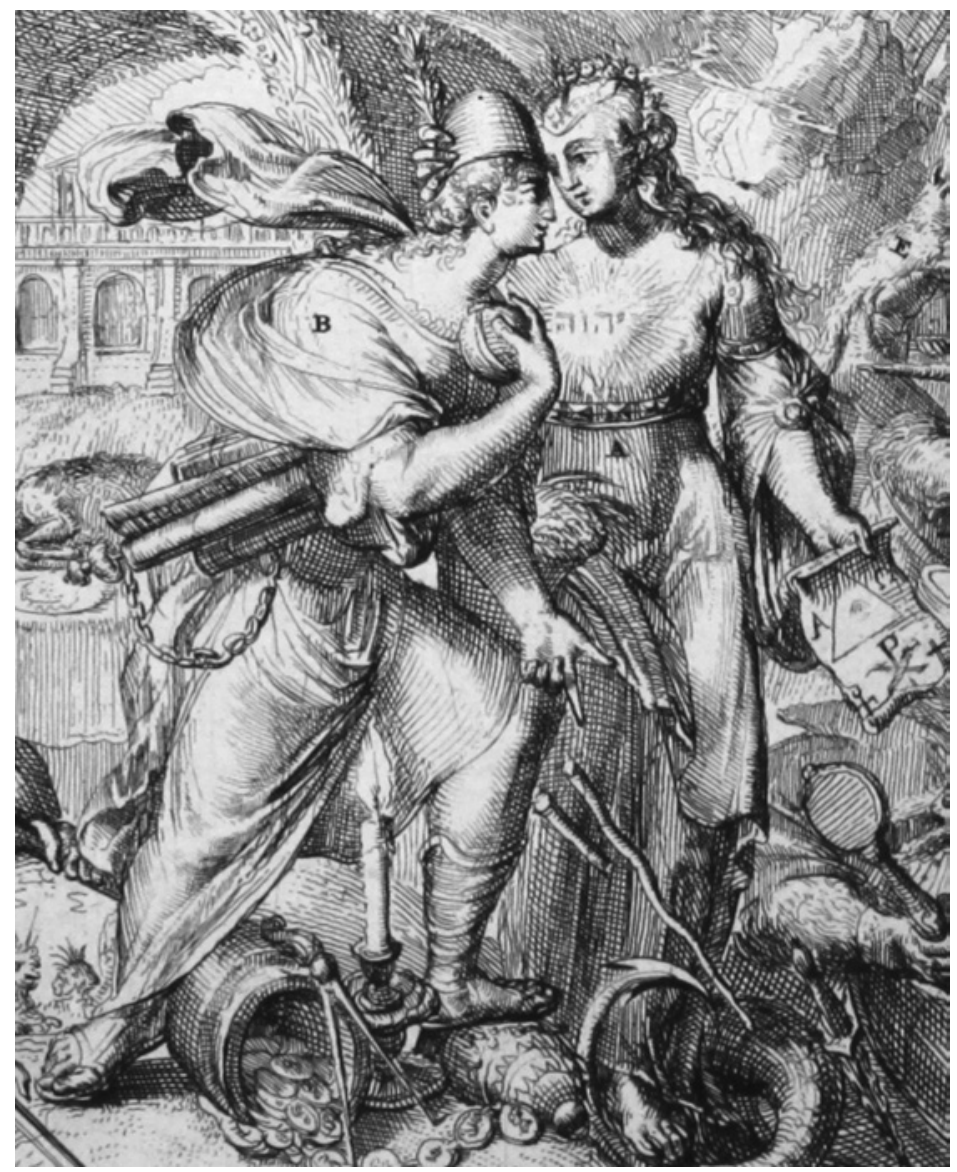

FIGURE 8.5 De Vreede van Gods Kerk [The Peace of God's Church] and Haar vlugge en werkelijke Zuster, de Vryheyd, om de $H$. Verborgenheden te doorzoeken [Her quick and active sister Freedom to inquire into the Holy Mysteries], details A and B of plate 35. Private collection

form of research that is allowed "without fear of schism," De Hooghe explicitly adds. The consequence of such research by individual believers might result in different opinions on different matters. De Hooghe's answer to such diversity is given in the form of a pomegranate, "in which so many tasty and salutary parts are kept together in one peel."43 The pomegranate indicates De Hooghe's preference for religious freedom and variety within the church, as long as the peel holds them together.

43 De Hooghe, Hieroglyphica (see above, n. 3), pp. 269, 270. See also ibid., p. 438. 
Nevertheless, a more conservative, orthodox position is also found in Hieroglyphica's chapters. In chapter 4, for example, predestination is lauded in figure L, The Virgin, the Super Natural religion. She is described as "a New Creature, denoting that the kingdom of God already begins in our souls; she feels the undeserved Grace of her Predestination and Election for Eternal Bliss." ${ }^{44}$ In chapter 61 figure $\mathrm{F}$ denotes the National Synod of Dordrecht (1618/9) which condemned the Arminian, Remonstrant view on predestination (Figs. 8.6 and 8.7).

De Hooghe talks about this figure with respect: she is an "honourable and wise, divine woman, with no intention of ruling over people." She deliberates carefully, uses the original Hebrew biblical text and the writings of the Apostles and the Church Fathers, and in her hand she holds a sieve to sift the wheat from the chaff. In her lap we find a reference to the topic of predestination, namely "the steel hammer with diamond nails of the Divine Election and Predestination, triumphant over the Quarrelers." And if there was any doubt left, De Hooghe ends his explanation by stating that this was truly "a council of all nations, who sent their brightest minds."

Although the topic of predestination remained important to the maintenance of orthodoxy - in 1755 Antonius van der Os (1722-1807) was dismissed for his alleged Remonstrant ideas about predestination ${ }^{45}$ - a trend in the early eighteenth century sought to "soften the doctrine of predestination." ${ }^{46}$ De Hooghe's ambiguous approach to the Arminian controversy might indicate that opinions were shifting, indeed, toward a focus on unity instead of stringent dogmas. The presence of Christian predestination among gods of Fate invented by pagans seems to suggest this unity, within either a conservative or a more radical view.

Another example of ambiguity is found in De Hooghe's treatment of the devil, both in his chronological and his thematic etchings. Throughout Hieroglyphica we encounter ambivalence about the devil. On the one hand, in his chronological chapters De Hooghe endorses the real existence of the devil, his role in the

44 De Hooghe, Hieroglyphica (see above, n. 3), pp. 64, 65.

$45 \mathrm{~J}$. van Eijnatten and F. van Lieburg, Nederlandse religiegeschiedenis (Hilversum, 2005), pp. 216, 217. See also R. A. Bosch, Het conflict rond Antonius van der Os, predikant te Zwolle 1748-1755 (Kampen, 1988).

46 Johannes van den Berg, Religious Currents and Cross-currents: Essays on Early Modern Protestantism (Leiden, 1999), pp. 263, 264. 


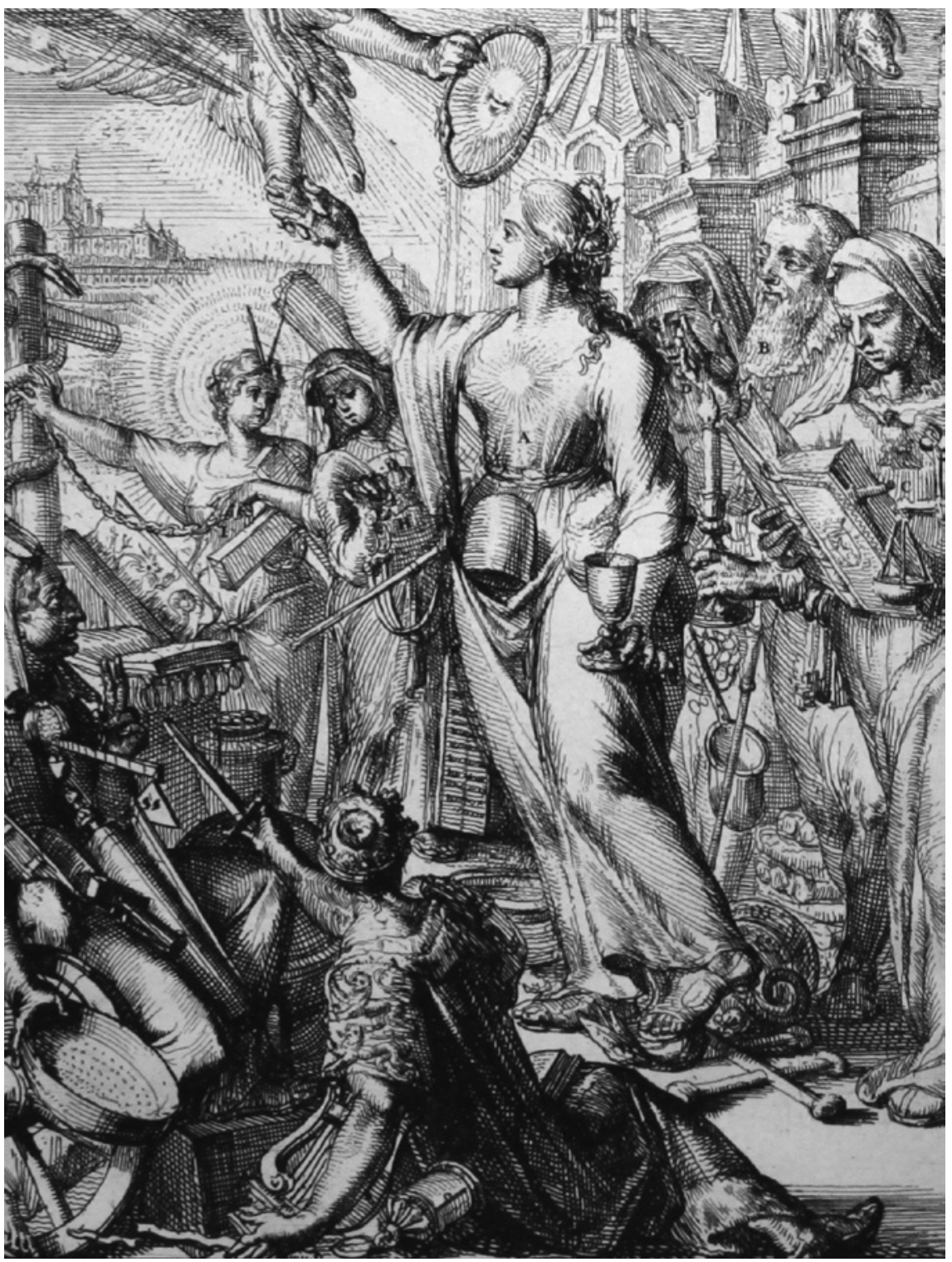

FIGURE 8.6 Van de Gereformeerde Godsdienst [On the Reformed Religion], plate 61, in: Romeyn de Hooghe, Hieroglyphica (Amsterdam, 1735). Private collection

Fall and in sacred history. Moreover, he explicitly states that the third-century theologian Origen was wrong to interpret the snake from Genesis allegorically. De Hooghe emphasized that the devil was actually present in Paradise in the 


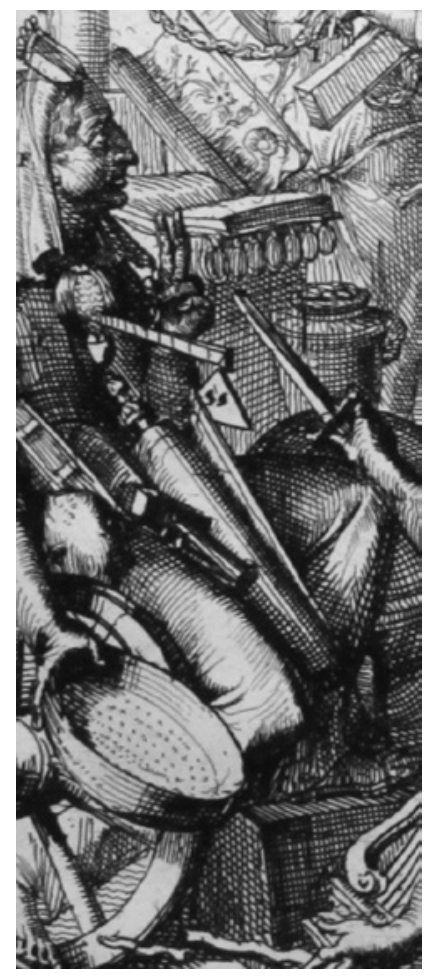

FIGURE 8.7

The National Synod of Dordrecht, detail F from plate 61

form of a snake. ${ }^{47}$ The devil is depicted in several etchings in Hieroglyphica. Chapter 4 presents the Lion of Judah that will conquer the devil, in chapter 33 we find a reference to the serpent/dragon, chapter 51 tells us that Judas devoted himself to the devil, and in chapter 58 the devil tries to destroy the Church. In the illustration for the parable of the wheat and the tares ${ }^{48}$ in the book Het voorhof der ziele [The Forecourt of the Soul] (1668) by Frans van Hoogstraten (1632-96), it is De Hooghe who casts the devil as the unidentified enemy sowing weeds among the wheat. ${ }^{49}$

On the other hand, there are examples that question the devil's origins and render his power less visible. These sorts of representations contributed to a trend in which the devil was not taken so seriously. Wherever the devil occurs in De Hooghe's account, he is positioned very small in the background; evil has

\footnotetext{
47 De Hooghe, Hieroglyphica (see above, n. 3), p. 145.

48 Matt. 13,24-30 and Matt. 13,36-43.

49 Wilson, The Art of Romeyn de Hooghe (see above, n. 12), p. 155.
} 
been brought to this world first and foremost by human clerics. ${ }^{50}$ Furthermore, in chapter 37 devil worship is mocked as an idiotic and stupid practice, and in chapter 56 the figure of the frank man (a layman who in the run-up to the Reformation starts to read the Bible for himself) finds out that there are no ghosts and devils in the Bible. ${ }^{51}$ Most important for this topic, however, are the comparative chapters 28, 'Van de Goede en Kwaade Goden' [Of good and evil gods], and 29, 'Van de Kwade Goden' [Of evil gods], where we find the Christian devil juxtaposed with pagan 'evil gods' (Figs. 8.8 and 8.9).

In chapter 28 De Hooghe describes the existence of good and evil gods in many religions, starting with the following reflections:

Most among the pagans, yes even some of the so-called Christians, thought that the Eternal Being, which they envisioned their Creator and Keeper, was Infinitely good, therefore nothing could come from him but blessing, [therefore] necessarily another Being or principle must exist, obstructing the good, or pouring out evil on them. ${ }^{2}$

De Hooghe proceeds with his engraving and an explanation of the good and evil gods in many pagan religions. Among the Egyptians, for example, Osiris was the good god and Typhon the evil one. Visually, many of these evil gods are depicted in the same manner, as dragon-like creatures with horns, claws, and sweeping tails. Such figures are found, according to De Hooghe, among Indians in Kolkata, among Japanese, Koreans, and Slavs, and even among Jews and Christians. With regard to Christianity, De Hooghe refers to the devil as the "seducer from the garden of Eden," a standard biblical description (Fig. 8.10). Without saying so explicitly, this positioning of the Christian devil among all kinds of false heathen evil gods and fairy-tale creatures such as ghosts, phantoms, and fairies suggests a rejection of the devil's existence as just one of many religious fabrications. ${ }^{53}$

This critical attitude is substantiated by De Hooghe's description of the contemporary state of belief in the devil:

\footnotetext{
50 De Hooghe, Hieroglyphica (see above, n. 3), p. 277.

$5^{1}$ De Hooghe, Hieroglyphica (see above, n. 3), p. 406.

$5^{2}$ "De meeste onder de Heydenen, ja zelfs eenige der zoogenaamde Christenen, hebben gemeent, dat het Eeuwig Weezen, het welk zy stelden voor hunne Schepper en onderhouder, was Oneyndig goed, en dat daar niets uyt konnende voortvloeyen als zegen, noodzakelyk een ander Wezen of beginzel moest zyn, het welk zulken goed belette, of kwaden op haar uytstortte." De Hooghe, Hieroglyphica (see above, n. 3), p. 237.

De Hooghe, Hieroglyphica (see above, n. 3), pp. 237, 238.
} 


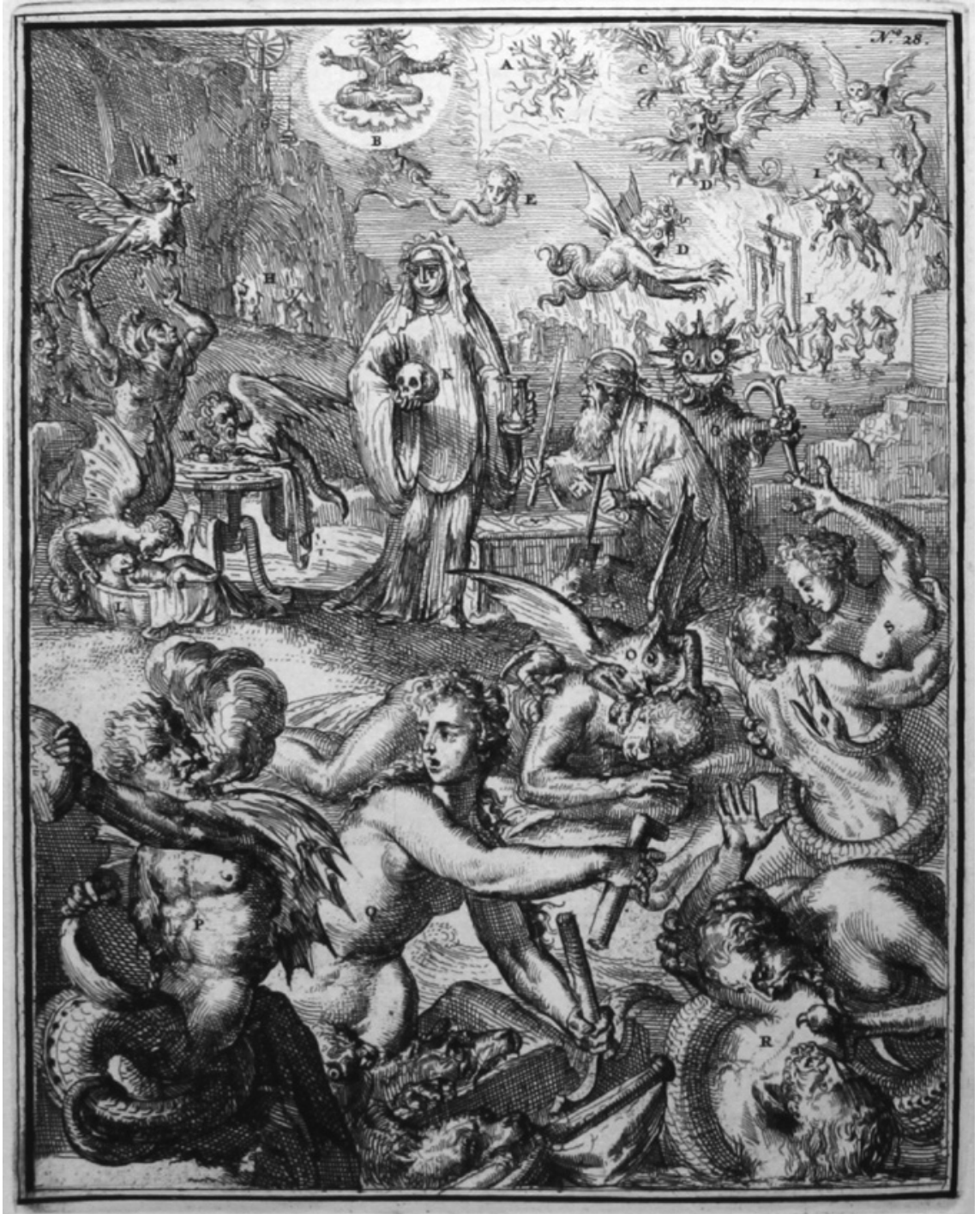

FIGURE 8.8 Van de Goede en Kwaade Goden [Of good and evil gods], plate 28, in: Romeyn de Hooghe, Hieroglyphica (Amsterdam, 1735). Private collection 


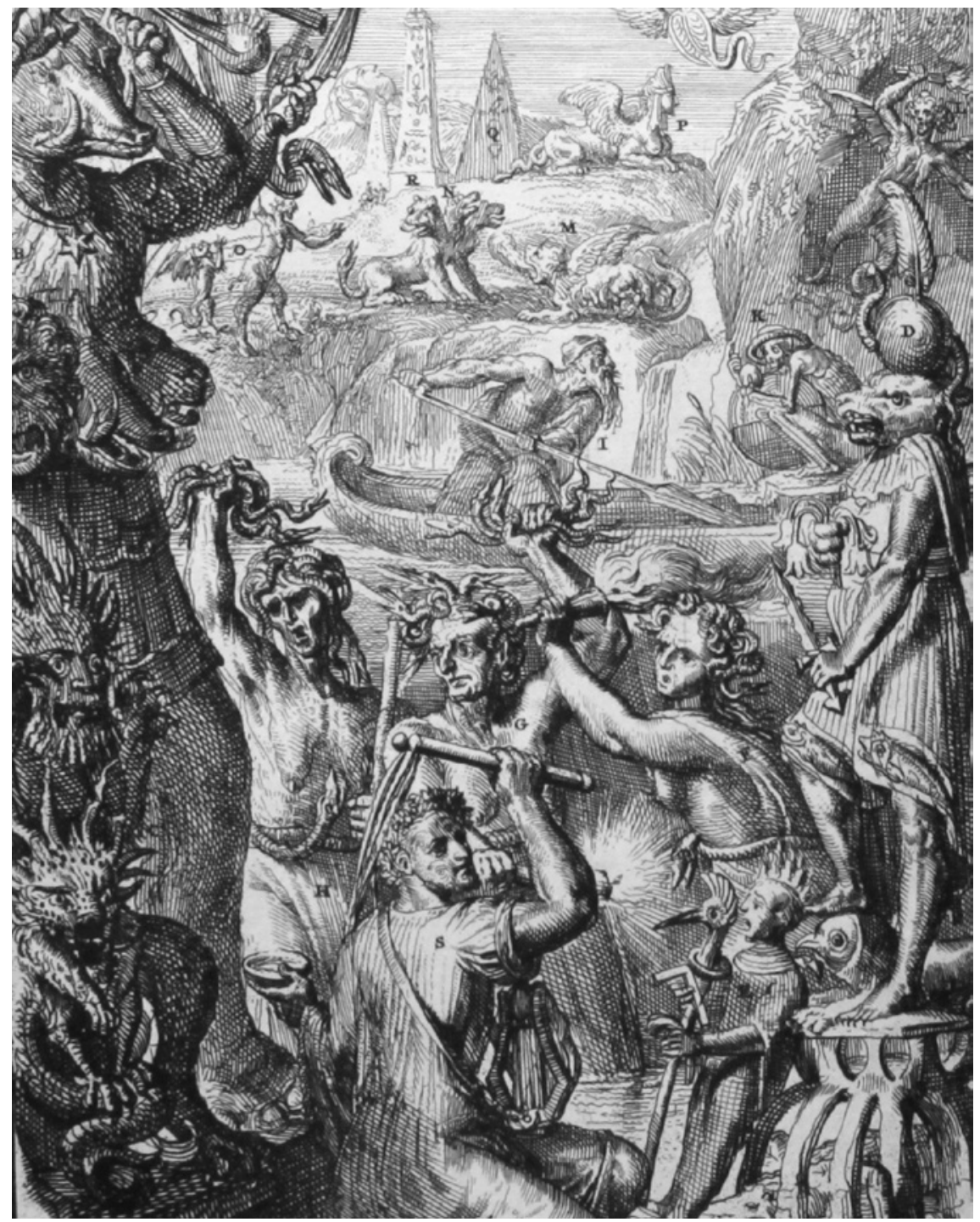

FIGURE 8.9 Van de Kwade Goden [Of evil gods], plate 29, in: Romeyn de Hooghe, Hieroglyphica (Amsterdam, 1735). Private collection 


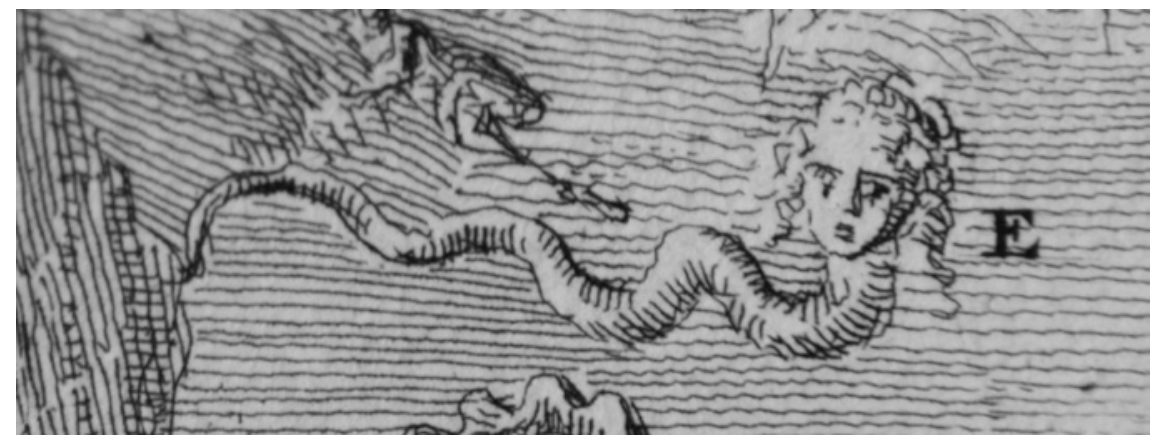

FIGURE 8.10 Den Verleyder in 't Hof van Eden [The Seducer in the Garden of Eden], detail of plate 28, in: Romeyn de Hooghe, Hieroglyphica (Amsterdam, 1735). Private collection

Although in my native country there are some impetuous thinkers who rudely mock ghosts, and even would want to banish the devils themselves out of the Bible, I, however, want to leave behind some [descriptions of] ghosts which mean something, so they can be used for countries or people who reason a bit less and believe a bit more. ${ }^{54}$

"Impetuous thinkers" is De Hooghe's clear reference to the notorious Balthasar Bekker (1634-98), who in his De betoverde weereld [The enchanted world] $(1691-3)$ denied the power of ghosts and devils to act upon the material world and to influence humans. By describing Bekker as an "impetuous thinker," who would even want to banish the devil from the Bible, De Hooghe insinuates that in his opinion Bekker had crossed the line. Reading more closely, however, we see De Hooghe explaining his own treatment of ghosts: "it can be used for countries or people reasoning a bit less" [my emphasis], as opposed to his own country, the Dutch Republic, where people no longer believed such things. ${ }^{55}$

In fact, Hieroglyphica contains ideas similar to Bekker's. Bekker's aim was to purge religion of the idolatrous elements that had infected Christianity, and he did so through his consideration of the topic of spirits and the devil, having thoroughly researched the meanings of biblical words in their original languages. Bekker believed in angels - spirits without bodies - on the authority of the Bible. Where the Bible was clear about the functioning of angels, their

54 De Hooghe, Hieroglyphica (see above, n. 3), p. 237.

55 De Hooghe, Hieroglyphica (see above, n. 3), pp. 283, 284. Pride in his country is also found in idem, Spiegel van Staat (Amsterdam, 1706-7), in which he cannot stop praising the goodness and the decency of the Dutch people. 
existence should be accepted, even if reason or experience would not support such a supposition. But Bekker's point was that Scripture was not always clear about the actions of spirits. For instance, the word 'angel' also meant 'messenger' and 'Satan' also meant 'opponent,' and these words were sometimes used to characterize the actions of humans. And although the Bible did speak of the actions of good spirits, it did not mention the deeds of bad angels or devils, Bekker argued. Moreover, the Bible explicitly related how the devil and his bad angels had been chained and thrown into hell, so they were not capable of performing actions on earth. Eventually Bekker's criticism on the States Translation and alternative Bible exegesis became the main reason for his condemnation. ${ }^{56}$

De Hooghe's skepticism is not an isolated case. Others, and not only Bekker, questioned the powers of the devil, and in some cases doubted his existence. The publisher Willem Goeree $\left(1635^{-1711)}\right.$ saw the seducer in Eden to be not some evil spirit or fallen angel but rather a representation of the base, fleshly desires of human beings. And De Hooghe's colleague, the painter Zacharias Webber (1644-96), for instance, bluntly stated that when the Bible spoke about the devil, this was actually a reference to the dark and evil hearts of human beings, not a remark about some sort of fallen angel. Still, Webber's writings seem contradictory, as he stressed the literal truth of the Bible several times. ${ }^{57}$

De Hooghe also remains undecided on such matters. After his critical comparison in chapter 28 , plate 29 in the following chapter again shows evil gods taken from different religions, all depicted in a dragon-like manner, with claws, wings, and fangs, this time unaccompanied by the biblical devil. This chapter ends by making a sharp distinction between pagan idolatry-which had also influenced the Jews - and the true Christian religion. Here once again we encounter a sacred history of religion that marks a firm divide between Christian religion and pagan idolatry.

It seems that De Hooghe's overall take on the devil is quite similar to the conclusions reached by the lay admirers of Bekker well into the eighteenth century. Most of these people, when called to account by church authorities, recanted their more extreme opinions. They all eventually admitted that the devil existed and had played a role in the deception of Adam and Eve. They were not willing to make statements about how exactly this worked in people's lives, as they personally had not felt themselves affected by good or evil

56 Andrew Fix, Fallen Angels: Balthasar Bekker, Spirit Belief, and Confessionalism in the Seventeenth Century Dutch Republic (Dordrecht, 1999), pp. 59-74.

57 Frits Praamsma, Zacharias Webber (1644-1696): Irenisch lutheraan-verlicht protestant (Delft, 2013). 
spirits. Most often they appealed to the notion that they did not know how the devil worked, and therefore did not want to make a statement about the matter. Michiel Wielema suggests that such sentiments may have existed even among ministers. ${ }^{58}$ In De Hooghe's words: "Our understanding of Angels and [demonic] powers remains confused," and, "the holy scriptures tell us that they are legion, but does not tell us what they are." They are the "executors of God's will," but the Bible provides no ground for elaborating further details about the devil, argues De Hooghe.

Another important matter in the religious debates of the late seventeenth century concerned how deceitful leaders could and did corrupt religion. Hieroglyphica contains a strong current of anticlericalism. Whereas some view the presence of such anticlericalism as characteristic of libertine and radical antireligious sentiments, historians like J. S. Barnett in his Idol Temples and Crafty Priests and Justin Champion in his Pillars of Priestcraft Shaken have shown that matters were more complicated, not least because anticlericalism was firmly rooted in Christian polemics and apologetics, used most often to criticize the Catholic clergy. In Hieroglyphica we find a similarly differentiated use of the discourse on clerical office. First, the partisan anti-Catholic polemic is present in at least eleven plates of Hieroglyphica where De Hooghe points to the deviation from true piety by the Catholic Church in general and its priests in particular (Fig. 8.11). Whenever priests or monks are depicted in Hieroglyphica they are presented as lazy gluttons and religious deceivers who enrich themselves through simony. 59

Another object of anticlerical criticism and derision was Muhammad. Protestants and Catholics may have accused each other of priestcraft, but when it came to Islam they stood on the same side. (Fig. 8.12) Ever since Islam's rise, Christians had considered Muhammad a lusty fraud, and an epileptic to boot, a deceiver who had cobbled together elements from Christianity with heretical ideas into a religion that persuaded Muslims to believe that he was Allah's prophet.

$5^{8} \quad$ Michiel Wielema, The March of the Libertines: Spinozists and the Dutch Reformed Church (1660-1750) (Hilversum, 2004), pp. 58-78.

59 De Hooghe, Hieroglyphica (see above, n. 3), pp. 407, 422, 430, 432, 347, 315, 316, 348, 349, 365,381 . 


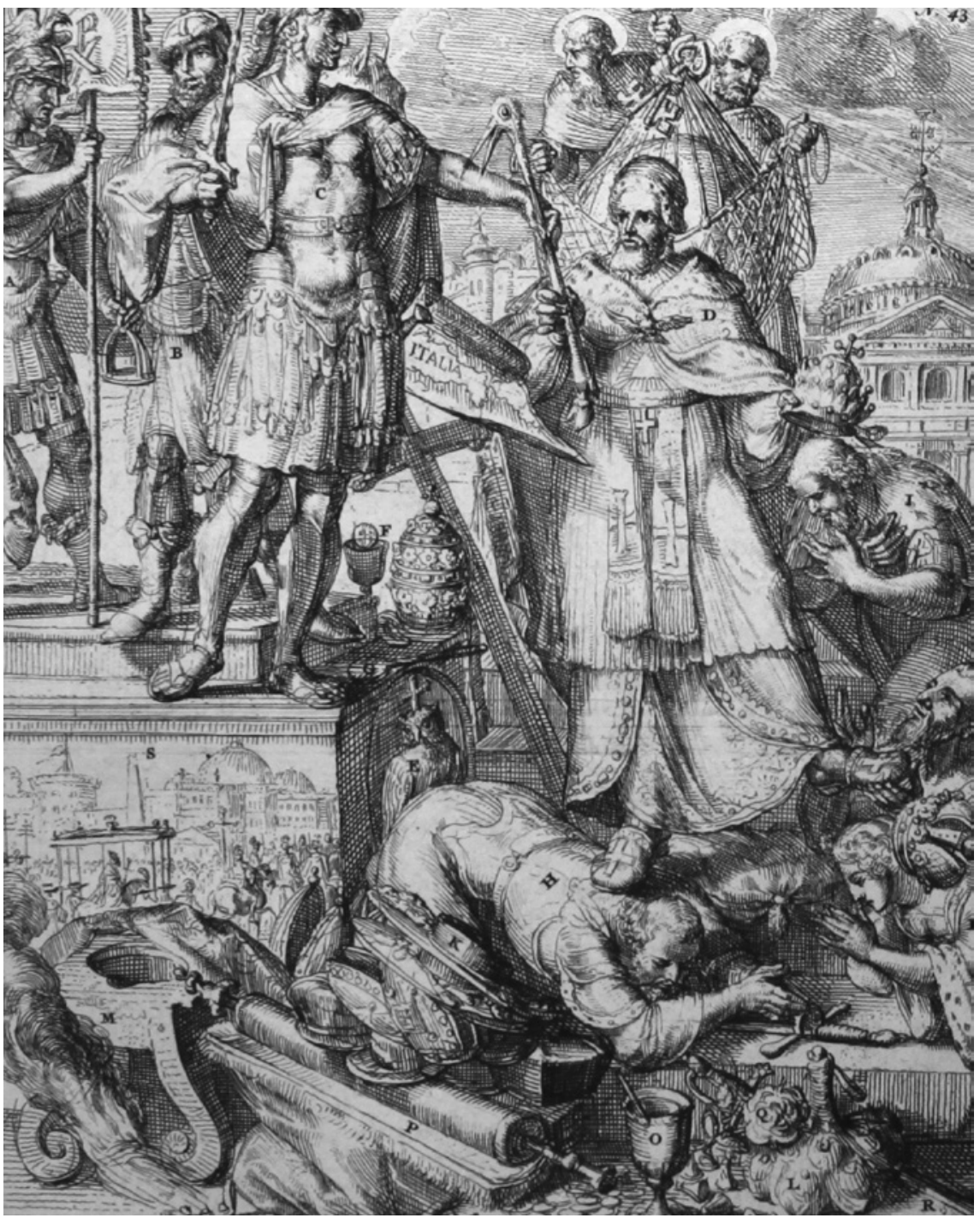

FIGURE 8.11 Van den Indrang tot Oppermacht der Roomsche Stoel [On the Ambition of the Roman Pontiff for World Supremacy], plate 43, in: Romeyn de Hooghe, Hieroglyphica (Amsterdam, 1735). Private collection 


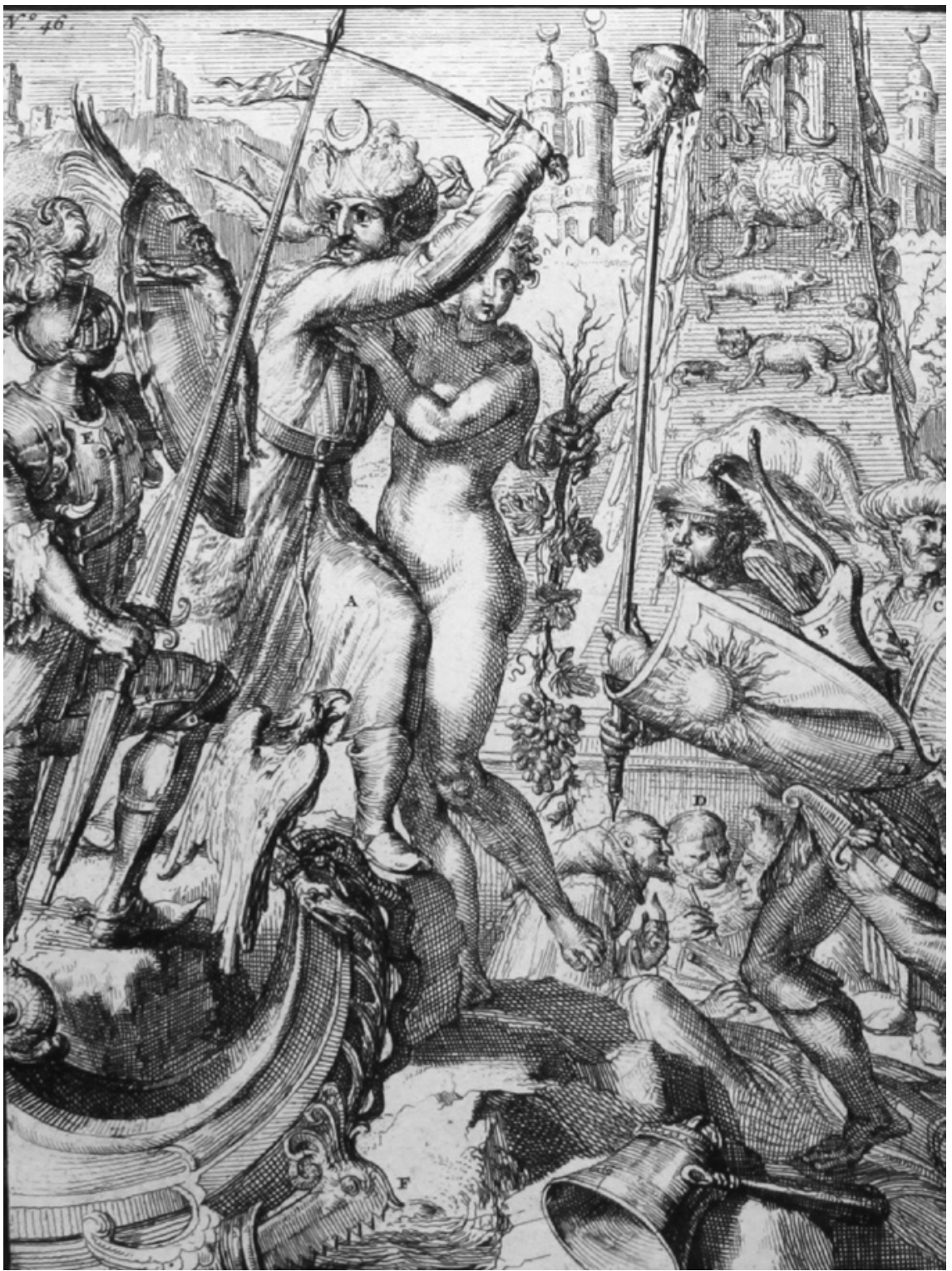

FIGURE 8.12 Van de Mohammedaansche Beginsselen [On the Mahometan principles], plate 46, in: Romeyn de Hooghe, Hieroglyphica (Amsterdam, 1735). Private collection 
So far nothing new. New, however, was the development that the more radical thinkers did not restrict their anticlericalism to Catholic or Muslim authors but broadened it to religious leaders in general, including those of their own confession. Adriaan Koerbagh (1633-69), the ally of Spinoza, for example, stated that Moses proved no exception to the rule: he too was an imposter who had faked having direct contact with God to keep the Israelites in check. ${ }^{60}$

De Hooghe is, again, ambivalent on the matter. There are many examples in Hieroglyphica that praise Moses as a true religious leader, divinely ordained. In chapter 6 of Hieroglyphica, for instance, Moses is commended as the historian of the earth's creation, and it is simply said that he had been inspired by the Holy Ghost to write the book of Genesis. Intriguing here is the passage in which De Hooghe states that Moses did actually meet with God, and that heathen imposters imitated having such an encounter. However, there are also signs of a more suspicious view of Moses, for example when De Hooghe relates how Moses's contemporaries accused him of fraud, a charge De Hooghe does not contradict. More critical, however, is the artist's visualization of the prototype of 'the religious imposter' in front of a mountain in plate 59, as "the distance from the eye" [i.e., the absence of witnesses] must support the deceit (Figs. 8.13 and 8.14). ${ }^{61}$ Although De Hooghe mentions historical leaders such as Muhammad or Lycurgus in this regard, the conception might have influenced his take on what happened during Moses's visit to Mount Sinai. Referring to the stone tablets, De Hooghe states that they are "possibly the work of Angels and the engraving of God's Incomprehensible Hand."62 The crux here is of course in the word 'possibly,' suggesting that we just don't know what happened there, as no witnesses were present.

Although Moses was the most famous example of a leader receiving the divine laws on a mountain, and in Hieroglyphica he also stands in front of a mountain, De Hooghe provides no further elaboration. Again, such reticence could conceal one of two attitudes. Either De Hooghe is making a distinction between pagan imposters and sacred priests from the Bible, believing that Moses had a real meeting with God out of sight of witnesses, or he is insinuating that priestcraft was not restricted to the 'other' religions but was present even in a core element of Judaism and Christianity: the Ten Commandments.

\footnotetext{
6 Adriaan Koerbagh, A Light Shining in Dark Places, to Illuminate the Main Questions of Theology and Religion, ed. and trans. Michiel Wielema (Leiden, 2011).

61 "Een Berg ziet men achter hem, om dat die afgelegenheyd van 't Oog, het bedrog dient te steunen, als in Mahometh, Lycurgus, en Numa Pompilius...." De Hooghe, Hieroglyphica (see above, n. 3), p. 424.

62 “... mogelyk 't werk der Engelen, en 't grafeerzel van Gods Onbegrypelyke Hand...." De Hooghe, Hieroglyphica (see above, n. 3), p. 173.
} 


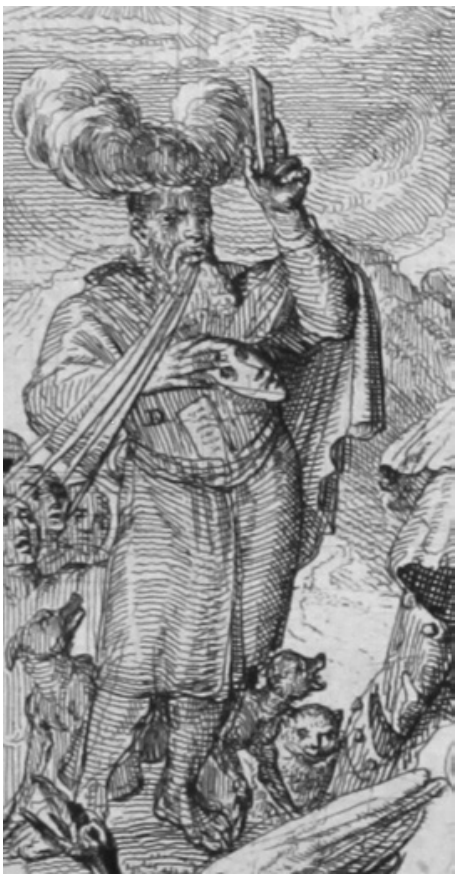

FIGURE 8.13

Wysmaking [Fooling] and Aanrading

[Recommendation], detail D from Van de Hervorming [On the Reformation], plate 59 in: Romeyn de Hooghe, Hieroglyphica (Amsterdam, 1735). Private collection

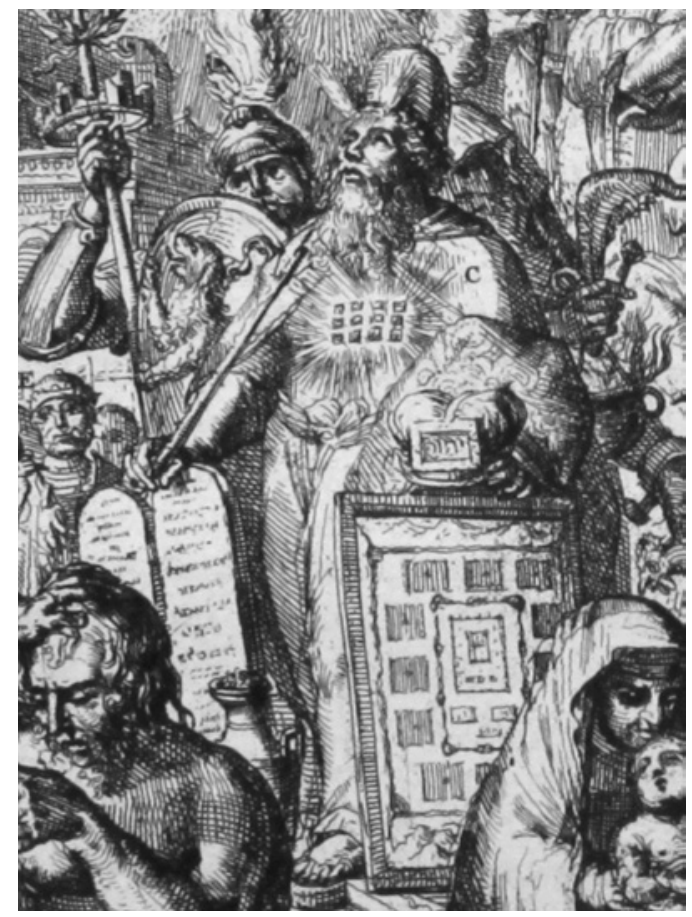

FIGURE 8.14

The lawgiver Moses, detail C from Van Gods Volk [Of God's People], plate 14: in: Romeyn de Hooghe, Hieroglyphica (Amsterdam, 1735). Private collection 
A last remarkable ambiguity in this context lies in how clerical deceit is judged. Here also two possible views suggest themselves. On the one hand, De Hooghe denounces clerical fraud and tries to unmask these imposters in his book. On the other, however, Hieroglyphica endorses the benefits of such religious deceit. In De Hooghe's words:

These heathen priests are villains, but we have to be grateful to them because thanks to their imposture many dangerous murders, cases of poisoning and other atrocities have been prevented. ${ }^{63}$

For if they [the masses] knew clearly all this, there would not remain enough fear amongst them to keep them in check. Even if it counters reason that struggles for the naked truth, and wants to remove all superstition, it is politically expedient to increase superstition. ${ }^{64}$

Important in this 'white lies' position is De Hooghe's depiction of the hereafter. In line with his skeptical view on the devil, we also find a skeptical opinion on his residence: hell. The final chapter, on the hereafter in various religions, begins with a remarkable note:

A worldly reward was too limited to bring forth great merits, or restrain scoundrels, while some acts can escape justice, like perjury, poisoning and the like. So, great minds thought it more efficient to perpetuate both punishment and reward. ${ }^{65}$

De Hooghe claims that the whole idea of eternal punishment or reward was invented by political leaders to encourage the good behavior of their citizens. Such a subversive claim in the introduction to the chapter indicates that De Hooghe was indeed influenced by a trend that valued religion less for the truths of its dogmas and more for its pragmatic utility.

The appreciation of clerical deceit is found mostly in the writings of radical and deist thinkers, who perceived religious leaders no longer to be representatives of God or a pantheon of gods but as clever statesmen adept at controlling the masses. Religious leaders were not the frontrunners in a sacred history guided by God himself; rather they were Machiavellian leaders, movers and shakers in a global history of religion. Although it is remarkable that this view is present in Hieroglyphica, it is my contention that this criticism of religious leaders and the behavior of believers is not primarily the result of a

63 De Hooghe, Hieroglyphica (see above, n. 3), p. 34.

64 De Hooghe, Hieroglyphica (see above, n. 3), p. 28.

65 De Hooghe, Hieroglyphica (see above, n. 3), p. 443. 
philosophical Enlightenment or the rise of comparative religion but is instead part of what is called the 'Long Reformation.' This label emphasizes the idea that the Reformation was not a demarcated historical event but a process unfolding over a long period. In its evolution the clergy was professionalized, and laypeople (including women) and even children profited from a "massive educational endeavour." Within the specific field of the history of religion, what is striking is the eighteenth-century adaptation of elitist humanist scholarship in theology and the history of the Bible for a lay audience, in books in the vernacular. ${ }^{66}$ Lay access to theology changed the relationship between clergy and laity from a hierarchical order based on authority to a more egalitarian constellation consisting of professionals and their interested public. ${ }^{67}$ Although this Long Reformation has been dated approximately from the late Middle Ages until the Thirty Years' War, there is no reason to insist that the process of an ongoing, 'further' Reformation ended in the middle of the seventeenth century. Indeed, it may have continued much longer, as many Protestants continued to see themselves as the Reformation's heirs. ${ }^{68}$

Another possibility is that De Hooghe was influenced by the distinction increasingly made between the elite and the 'common' believers. As historian Peter Harrison explains, the priestcraft theory provoked so many critiques that it was adapted into a version in which priests were conning their followers not for their own benefit but for reasons of state security and social order. The true core of religion was too delicate to be explained to simple believers, therefore it was better to teach them an outward religion which would at least make them better people. This new idea of the clergy's moral function was supported by the intellectual elite, who, because they were 'civilized,' needed no such paternalism itself but considered it necessary for the lower orders. ${ }^{69}$

66 Jeremy Gregory, 'The Making of the Protestant Nation,' in: England's Long Reformation, 1500-180o, ed. Nickolas Tyacke (London, 1998), p. 317. For professionalization of the clergy see: Peter van Rooden, 'Ministerial Authority and Gender in Dutch Protestantism around 180o,' in: Gender and the Christian Religion, ed. Anthony Fletcher, special issue of Studies in Church History 34 (1998), 301-11.

67 Remarkable is the rise of catechetical books, all meant to educate believers in their confessional interpretation of the Bible. See the contribution of Jo Spaans to this volume.

68 Thomas A. Brady Jr., 'From Revolution to the Long Reformation: Writings in English on the German Reformation, 1970-2005,' Archiv für Reformationsgeschichte 100 (2009), 48-64; Van Rooden, 'Ministerial Authority and Gender' (see above, n. 67).

69 Peter Harrison, 'Religion' and the Religions in the English Enlightenment (Cambridge, 1990), pp. 85-96. This arcane, true religious knowledge was passed on among the intellectual elite via coded language - according to De Hooghe via hieroglyphs. Only the elite were able to live according to the basic notions of true religions, without ceremonial and practical external help. See also Justin Champion, The Pillars of Priestcraft Shaken: The Church of England and Its Enemies 1660-1730 (Cambridge, 1992), pp. 146-7; Van Rooden, 'Ministerial Authority and Gender' (see above, n. 67). 
Although De Hooghe's account still differentiates between the antics of heathen imposters and the genuine message of Moses, his overall emphasis on the general presence of priestcraft in religion does indicate that the critique of 'other' leaders was to some extent also applied to his 'own' Protestant leaders, who are presented in an ironically idealistic manner. ${ }^{70}$

In conjunction with De Hooghe's distaste for clerical power, Hieroglyphica contains many criticisms of scholastic quarrels and expressions of yearning for harmony. It seems that his idea of true religion was not so much centered on the correct doctrines regarding every detail of faith; rather, he articulated a vision of a Reformed religion that followed Christ's fundamental ordinances, consisting of a few central tenets only and focusing on the believer's pious and humble attitude. ${ }^{71}$ Still, this shift from dogmatism to morality is nuanced by other parts of Hieroglyphica where De Hooghe's visualizes his abhorrence toward religious dissidents (who are condemned to hell) and people contesting the importance of the Bible. ${ }^{72}$

In Hieroglyphica De Hooghe made the unusual combination of some sort of history of religion and a pictorial lexicon of the symbolic images of ancient religions and their gods. The amalgam produced a rather ambiguous image of true religion. Through his lexicographical approach, De Hooghe was able to compare religions and religious matters on an abstract basis, resulting in a 'history of religion' approach. Here, the lines between Christianity and idolatry are blurred, and the general category 'religion' shimmers through. At the same time, however, De Hooghe's historical line foregrounds a confessionalized 'sacred history' which presents the Dutch Reformed Church as the true heir of original religion. The three cases discussed show that De Hooghe reflected on debates of his time but found it acceptable to present ambiguous and sometimes contradictory views, refraining from making an explicit judgment. Against the labeling of early modern religious authors as either Enlightened or radical, I have suggested here that one or another label cannot always capture a certain cluster of opinions so easily. The varied sentiments expressed mirrored

70 See Van 't Hof, 'Radicale, partisane ou idéaliste?' (see above, n. 26).

71 See my forthcoming $\mathrm{PhD}$ thesis.

72 De Hooghe, Hieroglyphica (see above, n. 3), pp. 427-33. 
(whether out of opportunism or not) an ambiguous attitude towards true religion. As we saw, De Hooghe was not the only person mixing different opinions on the content of true religion. His colleague, the painter Zacharias Webber, for instance, posits contradictory statements about Christ-sometimes the Saviour, on other occasions a pious example. ${ }^{73}$ The Mennonite preacher and physician Anthonie Van Dale (1638-1708) denounced oracles and was critical of the existence of ghosts, but he still believed that Jesus had freed people from demonic possessions. ${ }^{74}$ Willem Goeree can be seen as at once a pious scholar and a radical libertine; the painter Samuel van Hoogstraten (1627-78) brought forth logically opposed statements in his writings. ${ }^{75}$

Such ambivalent approaches illustrate that much early modern thinking about religion - especially when examining the 'elite of the skilled' instead of the professional theologians and philosophers-contained elements of several intellectual currents at once. Divergence of opinion did not always occur along the convenient divisions modern scholars have made distinguishing radical, moderate, conservative, or religious Enlightenments. The situation, at least in the work of De Hooghe, could be much more ambiguous. Such ambiguity nuances the influence of 'Enlightened' philosophical ideas and underscores the recent attention given to the broader historical criticism applied to biblical exegesis from within - in this case-Protestantism. ${ }^{76}$ This was combined with an ongoing demand for continued reformation, which included a critical attitude toward churches and religious leaders. Himself influenced by increasing notions of a more historical, critical history of religions, De Hooghe, with Hieroglyphica, contributes to the popularizing of the 'new science,' the history of religion, and offers evidence of a shift toward a less certain, less dogmatic, and more individual and pious conception of Christianity.

73 Praamsma, Zacharias Webber (see above, n. 58), p. 215.

74 Thijs Weststeijn, The Visible World: Samuel van Hoogstraten's Art Theory and the Legitimation of Painting in the Dutch Golden Age (Amsterdam, 2008), p. 40.

75 Jetze Touber, Spinoza and Biblical Philology in the Dutch Republic, 1660-1710 (Oxford, 2018), pp. 56, 57. See also the list at the start of this paper. Frederik van Leenhof wrote both the Cocceian Keten der Bybelse Godgeleerdheid, which has not been studied, and the Spinozistic and therefore very controversial Hemel op Aarde.

76 See Levitin, 'From Sacred History to the History of Religion' (see above, n. 1); Sheehan, 'Sacred and Profane' (see above, n. 21), esp. pp. 61-6. 